Portland State University

PDXScholar

8-1-1975

\title{
Construction and Implementation of an Individualized Math Program for Sixth Graders
}

Lynda Sylvia Hatch

Portland State University

Follow this and additional works at: https://pdxscholar.library.pdx.edu/open_access_etds

Part of the Science and Mathematics Education Commons Let us know how access to this document benefits you.

Recommended Citation

Hatch, Lynda Sylvia, "Construction and Implementation of an Individualized Math Program for Sixth Graders" (1975). Dissertations and Theses. Paper 2030.

https://doi.org/10.15760/etd.2029

This Thesis is brought to you for free and open access. It has been accepted for inclusion in Dissertations and Theses by an authorized administrator of PDXScholar. Please contact us if we can make this document more accessible: pdxscholar@pdx.edu. 
AN ABSTRACT OF THE THESIS OF Lynda Sylvia Hatch for the Master of Science in Education presented August 1, 1975.

Title: Construction and Implementation of an Individualized Math Program for Sixth Graders.

APPROVED BY MEMBERS OF THE THESIS COMMITTEE:

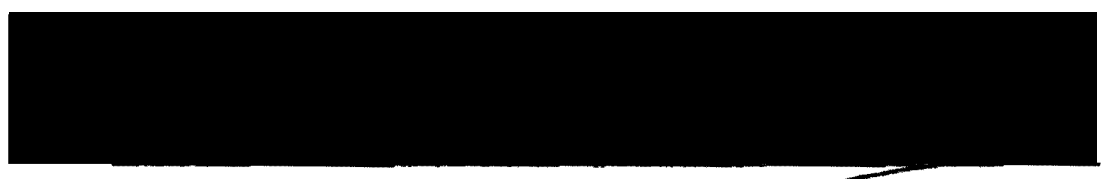

Colin G. Dunkeld, Chairman

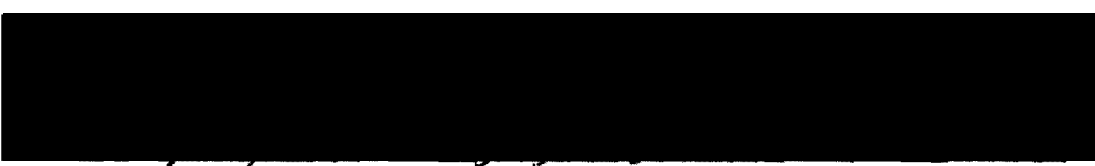

Making/L. Thomas

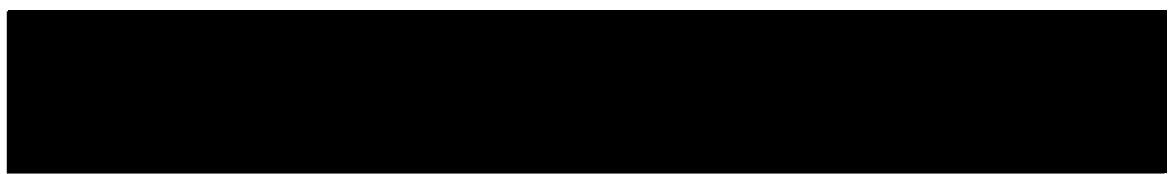

Mildred L. Bennett

The sixth grade teachers at Mooberry School in Hillsboro, Oregon were not pleased with the way they were teaching math. The students, grouped by ability, had a poor self-concept about math and felt "locked into" one class.

During the summer of 1973 , these teachers considered ways to change their math instruction. Reading was done to determine the most promising practice in math education in the United States. A successful approach to learning appeared to be individualized 
instruction, as is discussed in this paper. Many different individualized programs were studied, grouped into eleven general categories, and described in detail. The Mooberry sixth grade teachers adopted none of these programs, but instead developed a rotating system of math instruction.

The teachers prepared for this rotating system by developing a sequence of math skills, to span the sixth graders through the year. Each teacher was responsible for individualizing instruction in two or three units of the sequence. The writer developed units in division, plotting coordinates on a grid, graphing and geometry.

This rotating system of math instruction is individualized in that the students work at their own pace through the sequence of skills. The students move from concept to concept, and thus from teacher to teacher, gaining competence in as much of the cycle as they can master during the school year.

The writer has described her approach to the units she covers in the cycle. The textbook has been eliminated and task cards have been developed. Student booklets, answer books, a grade book and a report card have been designed. A typical math class and steps of the cycle are described in the paper.

The program has been used during the 1973-74 and 1974-75 school years. The teachers looked for evidence of success to indicate whether to continue their program in the same manner. In- 
formal notes were kept on the work habits, skills and attitudes of the students. A formal questionnaire was given to the student by the Educational Development Center at the end of the 1973-74 school year. The students indicated, through multiple choice questions, that they felt positive towards math instruction, that they deserved and were capable of good grades in math, and that they rated math as their favorite class. A narrative questionnaire was given to the « wriler's homeroom at the end of the 1974-75 school year. Those students wrote positive comments about the math system and again indicated how pleased they felt about their math abilities. Metro math test scores for 1974-75, by the Metropolitan Area Program Board, give the reader a background on the type of student in the Mooberry attendance area. These students were above regional and national norms. The principal of the school, Mr. Ron Stewart, wrote his evaluation of the program, which is included in the paper.

Questions have been raised about the program and have been listed for the reader. The teachers who developed the program hope, as more questions are raised and answered, that the rotating math program can change to meet the needs of the students, school and community.

The sixth grade teachers at Mooberry School feel pleased that they were able to develop a rotating system of math instruction for their students. Both the informal and formal data indicate that the 
program is enjoyable for the students, helps students develop selfconfidence in math education and helps the students gain competence in math skills and concepts. 
CONSTRUCTION AND IMPLEMENTATION OF AN

INDIVIDUALIZED MATH PROGRAM

FOR SIXTH GRADERS

by

LYNDA SYLVIA HATCH

A thesis submitted in partial fulfillment of the requirements for the degree of

MASTER OF SCIENCE

in

EDUCATION

Portland State University

1975 
TO THE OFFICE OF GRADUATE STUDIES AND RESEARCH:

The members of the Committee approve the thesis of

Lynda Sylvia Hatch presented August 1, 1975.
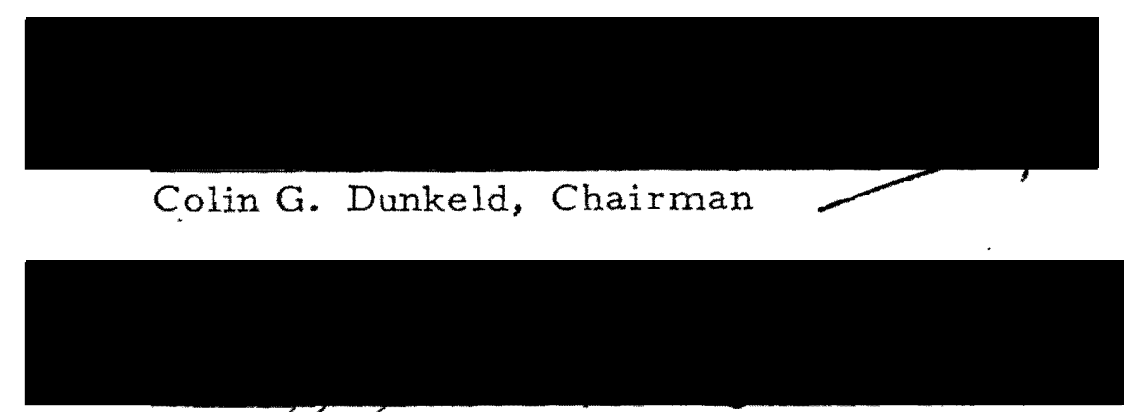

Maxine If. Thomas

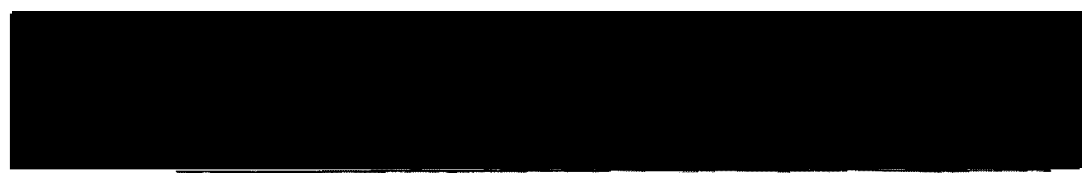

Mildred L. Bennett

APPROVED:

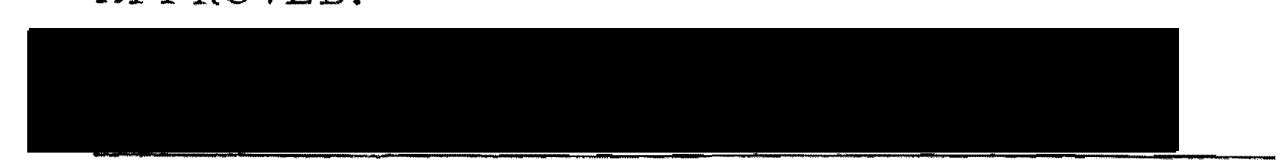

E. Dean Anderson

Acting Dean.

School of Education

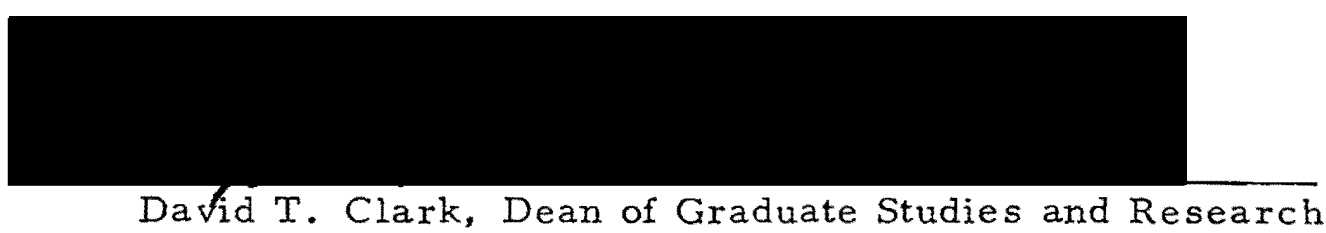

August 1, 1975 


\section{ACKNOWLEDGEMENTS}

I wish to express appreciation to Dr. Colin Dunkeld, Mrs. Mildred Bennett and Mrs. Maxine Thomas, my thesis committee members. Without their help and encouragement, this thesis would not have been possible.

As Chairman of my thesis committee, Dr. Colin Dunkeld spent many hours listening, encouraging and guiding me through the rigors of writing this thesis. His enduring patience, sound ideas and optimistic attitude will not be forgotten.

Mrs. Mildred Bennett gave me valuable assistance in determining that the mathematical aspects of my program were sound. Her enthusiasm for my math program helped me feel that writing this thesis was worthwhile.

Mrs. Maxine Thomas was always ready with an encouraging smile. She offered important ideas for clarity and consistency in my thesis.

My math program would not have been possible if it weren't for the innovative and flexible nature of the Hillsboro Elementary District \#7, under the leadership of Mr. Alton O. Smedstad, Mr. Howard Bay, the curriculum director, helped me feel my math program was in the best interest of children.

A special thank you goes to Mr. Ron Stewart, my principal, who gave me the permission and trust to develop my math program. 
TABLE OF CONTENTS

PAGE

ACKNOWLEDGEMENTS $\quad \ldots \ldots \ldots \ldots \ldots \ldots \ldots \ldots \ldots \ldots \ldots$ iii

LIST OF TABLES $\quad \ldots \ldots \ldots \ldots \ldots \ldots \ldots \ldots \ldots \ldots \ldots \ldots \ldots \ldots \ldots$

LIST OF FIGURES $\ldots \ldots \ldots \ldots \ldots \ldots \ldots \ldots \ldots \ldots \ldots \ldots \ldots \ldots \ldots$

CHAPTER

I INTRODUCTION $\ldots \ldots \ldots \ldots \ldots \ldots \ldots \ldots \ldots$

II CHANGES IN MATH EDUCATION........ 3

I Controversy Has Changed the Direction of Math Education ............... 3

II Problems in Changing the Design of Math Curriculum ............... 4

III Changes Require New Goals in Math Education $\ldots \ldots \ldots \ldots \ldots \ldots \ldots \ldots \ldots$

IV Math Education Must Change in Order to Relate to the World ............. 6

V Changing Approaches in Math Education.... 8

VI Summary $\ldots \ldots \ldots \ldots \ldots \ldots \ldots \ldots \ldots . . .6$

III OVER-VIEW OF INDIVIDUALIZED INSTRUCTION $\ldots \ldots \ldots \ldots \ldots \ldots \ldots \ldots 10$

I History of Individualized Instruction in the U.S. .................. 10

II "Wrestling" with Individual Differences .... 11

III Defining Individual Instruction $\ldots \ldots \ldots \ldots, 12$ 
IV Respect for the Learner ............ 13

$\mathrm{V}$ The Role of the Teacher in Individualizing . 14

VI Summary $\ldots \ldots \ldots \ldots \ldots \ldots \ldots \ldots \ldots \ldots$

IV . METHODS OF INDIVIDUALIZING MATH ... 20

I Assumptions of Individualized Instruction.. 21

II Team Learning $\ldots \ldots \ldots \ldots \ldots \ldots \ldots . \ldots . \ldots 23$

III Learning from Peer Teachers........ 25

IV Individualizing by Groups $\ldots \ldots \ldots \ldots \ldots$

$\mathrm{V}$ Working at an Individual Pace Through the Textbook $\ldots \ldots \ldots \ldots \ldots \ldots \ldots \ldots . \ldots 27$

Individual Assignments Per Child in the Text

Blackboard Appointment Approach Blackboard Listed Assignments

VI Sequential Learning Contracts ......... 31

VII Task or Assignment Cards .......... 32

VIII Learning Centers or Stations .......... 33

Definition

Criteria for Success

Teacher-Pupil Conference

Learning Center Example with

A Measurement Unit

Conclusion

IX Computer-Assisted Instruction ........ 37

X Incidental Approach to Learning Math .... 38 
XI Students Choose Interesting Math Topics..

Junior High Approach

Scheduling Optional Activities

Strand Approach

XII Students Choose Their Own Program....

XIII Summary $\ldots \ldots \ldots \ldots \ldots \ldots \ldots \ldots \ldots$

A ROTATING SYSTEM OF MATH

EDUCATION $\ldots \ldots \ldots \ldots \ldots \ldots \ldots$

I Hillsboro, Oregon .............. 46

II Mooberry Elementary School ......... 47

III Background .................. 49

IV District-Adopted Math Textbook ....... 50

V Task Cards $\ldots \ldots \ldots \ldots \ldots \ldots \ldots \ldots \ldots$

VI Starting the School Year............ 55

VII System of Rotation $\ldots \ldots \ldots \ldots \ldots \ldots \ldots . \ldots$

VIII A Typical Math Period .............. 59

IX Checking the Students' Work ......... 61

X Student Helpers ................ 62

XI Recording Students' Progress ......... 63

XII Reporting to Parents ............... 66

XIII Summary $\ldots \ldots \ldots \ldots \ldots \ldots \ldots \ldots \ldots \ldots$

VI EVIALUATION OF MOOBERRY SCHOOL'S ROTATING MATH PROGRAM........ 72 
I 1973-74 Multiple Choice Evaluation .....

Social Studies Questionnaire Math Questionnaire

Ability in Math

High School Graduation Position

Students Grading Themselves

Grade Capabilities

Favorite Subjects

Inte xpretation

II 1974-75 Narrative Evaluation

III Parent Response $\ldots \ldots \ldots \ldots \ldots \ldots \ldots \ldots .78$

IV Evaluation by the Principal ......... 79

V Metro Math Test Results........... 80

Summary $, \ldots \ldots \ldots \ldots \ldots \ldots \ldots \ldots \ldots \ldots \ldots, 82$

VII CONCLUSION $\ldots \ldots \ldots \ldots \ldots \ldots \ldots \ldots \ldots \ldots . . \ldots 4$

BIBLIOGRAPHY $\quad \ldots \ldots \ldots \ldots \ldots \ldots \ldots \ldots \ldots \ldots$

APPENDIX $\quad \ldots \ldots \ldots \ldots \ldots \ldots \ldots \ldots \ldots \ldots \ldots \ldots \ldots \ldots \ldots$ 


\section{LIST OF TABLES}

TABLE

PAGE

I

Frequency Graph

81

II

Distribution by Adjective Description ......

82 


\section{LIST OF FIGURES}

FIGURE

PAGE

I Basic Floorplan of Mooberry School

Sixth Grade $\quad \ldots \ldots \ldots \ldots \ldots \ldots \ldots \ldots$

II One Digit Division Unit Sample Task Card $\ldots . .54$

III Diagram of Math Rotating System ....... 60

IV Sample of Grade Book Recording Sheet...... 64

V Student Assignment Sheet $\ldots \ldots \ldots \ldots \ldots \ldots$

VI Math Report Card ................ 68 


\section{CHAPTER I}

\section{INTRODUCTION}

Education seems to pass through many trends, hopefully taking the best from each and moving along its path in history. In this paper, recent controversies and trends in math education in the United States will be discussed. The latest approach is individualized instruction. This term is becoming over-used and has many different meanings, but when clarified, it becomes a useful approach to learning .

An over-view of individualized instruction will then be given. Math education lends itself well to an individualized approach. Through current research, the writer has grouped individualized instruction in math education into eleven main types of programs. Each of these programs will be discussed, as a system that works for that school or class. No attempt will be made to say that any one system is the right one for everyone. Criteria will be given to help the readers determine which programs fit the most common standards for individualized instruction.

The construction and implementation of a rotating system of individualized instruction in math will then be described. This 
system is in operation at Mooberry School in Hillsboro, Oregon in a sixth grade team teaching situation. The school and community will be described briefly. Background will be given on how and why these teachers changed their approach from teaching math in ability groups to an individually paced instruction program. The program will be discussed in detail, as it works for these teachers. The part of the program that this writer is responsible for will be described in the greatest detail. Evaluation data will be presented. A brief conclusion will attempt to show the relationship between the various aspects of individualized instruction in mathematics. 


\section{CHAPTER II}

\section{CHANGES IN MATH EDUCATION}

We have lived through a revolution in mathematics and now it is time to look back càrefully to see what the past says to the future. Cohl (1974) says, "The revolution has passed, giving way to a more relaxed attitude toward math education." Less emphasis is being placed on language and symbols. More emphasis is being placed on content, individualization and subject relevancy to the students' lives.

\section{CONTROVERSY HAS CHANGED THE DIRECTION OF MATH EDUCATION}

A major part of the controversy today is the concern from parents that students are falling behind in their computational skills. There have been times when this was true in our rush to teach pure mathematics, applied mathematics and projects, says Davis (1974). However, education should not go back to the pre-new math program. Timmer (1974) says that if old math had been all that good, teachers never would have accepted the new math so readily.

It seems then, that the "right" math must lie somewhere between the dulling drill and practice of old math and the dulling 
intellectual discussions of the new math. Davis (1974) thinks that today's math program should help children "figure out the pattern" of a problem and then provide them with the skills to solve it correctly. This right mix of method and content will have to please parents, mathematicians, teachers and children.

\section{PROBLEMS IN CHANGING THE DESIGN OF MATH CURRICULUM}

There are two problems in designing a "right" math curriculum acceptable to all concerned groups, says Littledale (1973). Selection is the first problem. ' What is worth teaching to children at different age levels when the time available for teaching is limited and the quantity of topics that would be helpful for children to know is very large? Educators have to ask themselves if the topic will help children live effectively in the kind of society in which people are living today. For example, will it help them with problems they will encounter at the supermarket? Which math skills will contribute to the survival and effectiveness of the individual in a complex society?

Self-esteem is the second problem. Will the topic contribute to an indivudual's sense of personal worth? Will some children see the potential of becoming specialists in math, one of the sciences or some aspect of engineering? A sense of success enhances the sense 
of personal worth. Littledale (1973) adds: "The chain of motivation starts with interesting problems, problems that the child can solve, for solutions yield satisfaction and more interest."

\section{CHANGES REQUIRE NEW GOALS IN MATH EDUCATION}

A sound math program should have two goals, according to Littledale (1973). One is to give children a knowledge of basic mathematics and skills. The other is to help them learn independently the math they will need in an ever-changing society. As minicalculators become more common at lower prices, the need for arithmetic skills in most aspects of daily living will decrease. However, the need for quantitative thinking will increase. Math programs, then, need to stress problem-solving skills and the development of logical thinking. Both are necessary for the complexities of daily living.

Kidd (1970) has five goals for his instruction of math:

1. The ability to relate mathematical symbols and vocabulary to models.

2. The ability to manipulate mathematical symbols.

3. The ability to perceive the structure of mathematics.

4. The ability to think creatively about mathematics.

5. The development of favorable attitudes toward mathematics.

The sets of goals discussed here complement each other. Each 
person's goals for teaching mathematics will vary somewhat. The goals should, however, keep in mind the skills necessary for living in a complex world and the value of the individual's creative wonder of the world.

\section{MATH EDUCATION MUST CHANGE IN ORDER TO RELATE TO THE WORLD}

Kohl (1973) feels that many people try to begin their math program with where the students are "at". He says this is usually little more than channeling them through a traditional curriculum. Instead, he suggests that math education can focus on what students bring with them to school. This includes what they have learned on the playgrounds, on the streets, at home and on television.

Kohl believes that:

Instead of wasting endless time trying to get children to memorize meaningless and disconnected "facts" and recipes, we should use numbers inside the classroom to do what people use numbers to do outside the classroom - to measure, compare, analyze, predict.

Herald (1974) agrees with Kohl and Holt that math should be meaningful to the child in his world. For all ages, abstract concepts are easier to understand if they are aided by concrete materials. Herald (1974) says:

This is because concepts are developed by relating two or more ideas - and if these 
ideas are perceived through our senses, a little less effort is required than if we have to create them in our "mind's eye".

Herald relates his theory to reading. In reading, the child must know and understand what he is doing before he writes anything down. A teacher would never expect a child to spell the word "cat" unless he knew what a cat was. So, a child should not be asked to write down an arithmetic computation until he understands what he is doing.

Recently Kohl (1973) began to explore the mathematical skills and knowledge that play roles in people's everday lives and trans lated them into learning experiences that can extend into the class room and then back to the community. He had developed a list of different areas of knowledge that can be used as a guide to see where the students are in mathematics, so starting points for teaching can be determined. This list by Kohl (1973) will lead to different information and examples in different communities:

1. Mathematics is embodied in everyday life through the way people locate themselves and others in space.

2. Mathematics is embodied in the way people move around.

3. Mathematics is embodied in the way people locate themselves and others in time.

4. There is mathematics involved in each person's understanding of family relationships.

5. Mathematics is involved in sharing.

6. Accumulating.

7. Exchanging 
8. Gambling

9. Making, building and fixing

10. Dealing with machines.

11. Curiosity about numbers and relationships as abstractions.

\section{CHANGING APPROACHES IN MATH EDUCATION}

Many math programs will be changing in order to help students in their lives ahead. Educators today value active learning, student involvement, student participation and relevance, according to Kidd (1970). These changes may not be easy for some teachers.

As teachers read articles in education journals they often have the unspoken comment of feeling that it worked for that teacher in that situation but that doesn't mean it will work for them. Gilbert (1973) believes strongly that education needs change. He feels that if teachers don't initiate the reforms, they are likely to be imposed by some outside agent.

Wegner (1972) says that these are hectic times for school finances with millage failures becoming the norm. School staffs are frantically looking for a 6 capegoat for their instructional failures. Innovations often bite the dust, but this isn't always bad. However, one innovation that is not only surviving, but flourishing, is the practice of individualizing instruction. Though there are many definitions for individualized instruction, Wegener (1972) describes it as: "A mode of instruction that allows a teacher to compensate for 
individual student differences."

Individualizing instruction in mathematics is a major concern of teachers according to Cohl (1974). She says, "By relating math to the child's world, teachers can do more than individualize - they can personalize."

\section{SUMMARY}

Individualized instruction is a way to focus on the "right" math for each student. It gives the students the knowledge of math skills, helps them work independently and relates their learning to the outside world they bring with them and to which they will return. Many teaching approaches may need to be changed. Teachers will need to make these changes for themselves before outsiders do it for them. 


\section{CHAPTER III}

\section{OVER-VIEW OF INDIVIDUALIZED INSTRUCTION}

It may never be possible for teachers to plan and prescribe a school program that would allow for the most effective learning for every child, but many teachers have found a way to get away from a uniform instructional program, says Spaulding (1972). Teachers are moving to programs which take some account of the various rates of development and levels of achievement in their classes.

\section{HISTORY OF INDIVIDUALIZED INSTRUCTION IN THE U.S.}

During the colonial and early American period, schools were essentially ungraded and most instruction was tutorial, says Gibb (1970). Each child was able to progress at his own rate through the few texts that were available.

By 1870 , though, there were pressures to educate more children. Nearly all elementary schools in the United States were changed from ungraded to graded. Gibb (1970) says, "This movement was conceived and established in the faith that all men are created equal."

An individualized approach might have been best after all. The 
concept that all men are created equal should mean that each person gets an equal chance to learn. Equal learning requires a variety of approaches, or more commonly called individualized instruction.

\section{II. "WRESTIING" WITH INDIVIDUAL DIFFERENCES}

McBreath (1973) described how her son's wrestling program showed her the value of individualized instruction. When her son was in the eighth grade he tried out for the wrestling team. Mrs. McBreath had only seen wrestling on television and she was concerned that her son, Mike, would be mashed. Mike explained that he weighed 98 pounds so he would only wrestle boys who weighed between 96 and 103 pounds. If he had weighed 88 pounds he would have been in the 82-89 weight class. Everyone wrestled against. someone close to his own weight.

Mike made the team and Mrs. McBreath began to attend the matches. She discovered that when the smallest member of the team pinned someone in his weight class, he earned just as many points as when the biggest wrestler won in his class.

She wondered how the smallest member would look wrestling the biggest one. She took some pictures of a 76 pounder wrestling with a 180 pounder. Naturally, it looked ridiculous. Mrs. McBreath showed these pictures to teachers, who always laughed. Often, however, these same teachers would have a student reading at the 
third grade level and one reading at the eleventh grade level

"wrestling" with the same sixth grade social studies book.

This wrestling illustration clearly shows that programs which deal with individual differences are needed. Wrestling may provide a dramatic example, but learning in academic subjects requires just as much attention to individual differences.

\section{DEFINING INDIVIDUAL INSTRUCTION}

\section{Hunter (1973) explains:}

Individualization was born of both theory and practice. As educators looked for ways to accelerate learning and reduce failure, the differences in learners became undeniably significant. It was obvious that the most unequal education possible was to treat all learners as equals.

He adds that there has also been a humanistic concern that has emphasized each learner's importance, given him a voice in his learning and entitled him to make decisions about his educational goals.

Kaplan, et al (1973) define individual instruction as; "The process of developing and retaining individuality by a classroom organization that provides for the effective and efficient learning experiences of each class member." The goal is to make sure that no child becomes a permanent member of either a high, average, or low group. 
Hunter (1973) feels there are three ways to know that a student is truly involved in individualized instruction:

1. Is the learning task at the point of difficulty where previous knowledge leaves off and new learning begins?

2. Is the learner's activity to accomplish that task the most effective learning behavior for him at this time?

3. Is the teacher's behavior appropriate to the learner's achievement of goals?

Individualization and similar vocabulary are familiar words in every school and classroom, according to Hilton (1973). Teachers and administrators hear them almost daily and react to them in many ways. Hilton states:

Some applaud individualizing as the greatest thing since the one-room school; others greet it with the enthusiasm that accompanies a singer on a one-night stand, then wave it good-by with the same forgetful farewell. Some fleetingly consider, then veto it, while others try to ignore it.

Regardless of the exact words of the se various definitions of individualizing instruction, certain elements are present in most individualized programs. These programs take into account both the needs of the student and the needs of the teacher.

\section{RESPECT FOR THE LEARNER}

Trafton (1972) says that individualized instruction begins with a respect and concern for students as individuals and learners. The 
teacher must accept the responsibility for guiding and sequencing learning and organize it for instruction so that learning is continuous and natural. He says that classroom management programs should accomplish two objectives:

1. Enhance effectiveness of teachers in working with pupils.

2. Ensure quality learning experiences for children.

Before individualizing can become effective, there must be the individualization of the child. The teacher needs to be acquainted with the child and strengthen and broaden the relationship, according to Ashby (1974). At this point the teacher and student are ready for individualized instruction. Self-respect is being built in the child so he can increase his ability to respect others. Self-respect is necessary before he can accept the "setting apart" that individualizing in a large group involves. The student's respect for himself and others is a vital consideration in individualizing instruction.

\section{THE ROLE OF THE TEACHER IN INDIVIDUAIIZING}

Galton (1972) states:

Just as students are individuals with a need for individualized instruction, so are teachers: they must have individualized teaching methods both appropriate and comfortable for them.

All teachers will not approach individualizing in the same way. 
Whatever their approach, they need to be very alert and sensitive to the expectation each child holds for himself.

In the past there has often been a difference between teacher training and student needs, explain Reys and Post (1973). The teacher training has often stressed memorization and one-way communication with the teacher speaking to the child. Pupil dependence on the teacher has been fostered and there has been a major emphasis on teaching about the past and for the present.

Reys and Post (1973) feel teachers need to emphasize understanding instead of memorization. Communication should be a twoway, mutual exchange. Teachers should function as facilitators of learning, not as dispensors of information. The students should be prepared for the present and the future.

These changes do not come easily. Ziegler (1974) explained about beginning an open school and trying to find what approach to learning would best suit students. The teachers kept coming back to the idea that learning is an individual matter. The teachers found they had to do a lot of changing to create the right environment for learning. The students were pleased with the change and felt the school had a happy feeling.

When a teacher decides to make changes in the curriculum methods, these things should be considered, according to Redbird (1963): 
1. What specifically do you want the individual or individuals to learn?

2. Can the individual learn, and to what extent can he learn?

3. If the individual can't accomplish the learning, why can't he accomplish the learning?

4. What am I prepared to do, as a teacher, to help him accomplish the learning?

Sometimes students don't learn from individualized instruction.

They don't learn because some learning experiences are too often

the teacher's programs delivered to children on the teacher's terms

in the teacher's classroom, says Deturk (1973). He believes children

must assume these responsibilities in individualizing learning:

1. Children should create many of their own learning experiences.

2. Children should have the freedom to opt in and out.

3. Children should be able to select experiences from several available options.

4. Children should cooperate with and contribute to the group.

5. Children should be teachers.

6. Children can earn their own rewards by achieving their own goals.

7. Children should judge their own learning.

Deturk (1973) describes the learner in individualized instruction much

like the classic actor in a good production:

He will be prompted, guided, coached, and in general, helped in many ways by many people. But in the end, the success of the performance will depend upon how much responsibility the performer is allowed to assume, how much freedom of interpretation he is allowed to bring to 
his role, and how well he performs. In very much the same way, children must be permitted to exercise responsibility and imagination if an individualized program is to be successful.

\section{INDIVIDUALIZING HELPS THE DISABLED LEARNER}

Herald (1974) states:

We have programs to help the student with reading difficulties. These kids are scrutinized more closely and we think something stands in their way of reading. Unfortunately, not much is done about kids who have problems in math.

Often, their parents say not to worry because they couldn't do well in math either. The student's inability to understand in math turns to dislike, fear and often intense hatred of the subject.

Children have difficulty with math for several reasons, according to Herald (1974). A very familiar problem is inadequate prior instruction. This can also include immaturity. If a child was not ready for the subject matter he should not have been taught it. Emotional disturbances also interfere with school work, sometimes in all subjects and sometimes in just one.

A problem far more common than is generally realized, explains Herald (1974), is learning disabilities in math. Estimates of children having reading disabilities range from $3-30 \%$ of all children in school. Herald asks if there is any reason to suppose 
that the figure for math disabilities is any different.

These children with disabilities in math may have visual perceptual difficulties or poor auditory memory. Their spatial organization may be just poor enough to interfere with math but not show in other activities. As in reading, there is no single diagnosis for reading disabilities, so there is no single diagnosis for math disabilities. However, except for poor auditory memory, the problem seems more often to have something to do with the visual channel.

Besides the general category of "learning disabilities", some students may not be successful in math because of a reading problem. The child's lack of success may be characterized by incomplete homework, inaccurate work, unwillingness to explore by himself the field of math beyond the regular assignments, inattentiveness and a verbally pronounced discontent with the subject, according to Barney (1972). Each of these symptoms could be associated with a dislike of math, but each could also be attributed to reading problems associated with math, but not math per se.

Since some chịldren have learning disabilities and reading problems in math, it is essential that individualized programs are developed for each learner. The form these programs take may vary, but the regard for the individual student is essential. 


\section{SUMMARY}

The United States had individualized math in its early days, but swung away from it as more students attended school. Educators are finding a need to return to that concept as they see how it helps students with skills and self-esteem. The teachers need to find methods which are successful in their individualized teaching of math. Some re-learning may need to take place in order to develop an individualized approach which helps all students, especially those with learning disabilities and reading difficulties. 


\section{CHAPTER IV}

\section{METHODS OF INDIVIDUALIZING MATH}

Individual instruction in math can begin only when a teacher is aware of and sensitive to the needs of each learner. Each student has a particular level of ability, achievement and motivation. None of these is less significant than the others, says Graham (1972). Each student's needs are determined and then the student is placed in a particular level or subject. The lesson or plan of instruction is determined for that student.

Student failure doesn't exist. Graham (1972) believes that the only failure that exists is the teacher's failure to find appropriate materials and provide meaningful instruction. This can be a great blow to the ego of the teacher.

One of the most mistaken facts is that the teacher-pupil ratio is always one to one. This is true only part of the time. In some individualized programs a student may work all year alone, by himself, without help or interaction with fellow students. Graham (1972) feels:

At a time when people are having more and more difficulty relating to one another, education should be fostering exchanges between students 
and the bridging of communication gaps, not eliminating what little student verbalization does exist in the conventional classroom.

To individualize means to provide what is best for the learnet. This could be organized on an individual basis, a small group or partnership arrangement, or at times, instruction with the entire class.

\section{ASSUMPTIONS OF INDIVIDUALIZED INSTRUCTION}

Henderson (1972) states that several assumptions are made about individualized instruction. Some programs go "sour" when there is inflexibility in two or more of these variables:

1. It is possible to determine for each individual what is appropriate for him to learn - whether he makes the determination or his teacher.

2. Someone can determine the mode(s) of learning that are suitable for him.

3. Someone can determine the appropriate rate at which his learning should take place.

Henderson (1972) believes that:

- . our students should gain a thorough understanding of the concepts of math, should develop a liking for and an appreciation of math, and in return, should become creative problem solvers and logical thinkers. These objectives cannot be met... through the use of teacherless management systems that utilize self-study as the only mode of instruction.

Mathematical learning involves personal ways of providing individual instruction on several levels, says Henderson (1972). 
These three levels include work done in all areas of 1) group developmental approach, 2) self-paced progress of pupils and 3) independent self-selected activities. If students are too "locked into" one system, they may not be making the best use of their time and resources.

Henderson's (1972) levels can be considered as one set of criteria for determining the value of the following programs.

Individualized programs can also be judged on Ward's (1970)

more general evaluation. She feels approaches to individualization include two categories:

1. Rate of learning - takes substantial amount of advanced planning and preparation of, materials.

2. Student interests - uses independent study projects.

When evaluating the following individualized programs, these factors (Fisher, 1972) can also be considered:

1. Each student receives instruction at his own level of achievement.

2. A wide range of instructional materials is a vailable in the classroom.

3. Each child is permitted to progress at his own rate.

4. Each child is permitted to meet with the teacher individually or in small groups of students with similar problems.

5. Each child is permitted to check his own work as he works through the assignments.

6. The slow learner is not required to meet the standards of the groups and the bright child is permitted to explore areas of math in which he is interested. 
Eleven different approaches to individualized math will now be discussed. Other types of individualized programs exist, but the se eleven are representative of the most common types that could be used or are in use in elementary schools today. Criteria has been given which should help the reader evaluate these programs.

\section{TEAM LEARNING}

Team learning differs from the traditional programs of the whole class working together in that the students work in pairs. They progress at their own rates as a team. Homework is not collected or corrected by the teacher. Partners take quizzes together and receive the same grade.

This interesting example of team learning is happening in a seventh and eighth grade math class at Rancho Cañada Intermediate School in Whittier, California. This particular group of students has a high ability level, but the program has been used successfully at grades five and six, also. The reaction of the community and pàrticipants has been high.

Young (1972), the teacher of this program, feels the students learn more from each other than from the teacher. In a traditional program some students progress too quickly and some more slowly. Homework is usually looked over to see the number right, not why the errors were made. In team learning the students use an answer 
key and can get help if they want it. The lecture is eliminated, giving the teacher time to work with individuals. Some students do poorly on tests because they don't check their problems carefully, but when they work together, they help each ather with careless errors. They get higher grades and morale is boosted.

Before the school year begins, the year's course is planned carefully. Daily assignments are developed and written for each chapter of work. Answer keys and assignment sheets are duplicated.

Evaluation must be frequent to keep track of students' progress. Quizzes are given every four to six days. To ensure the understanding of the concepts that will be tested, cassette recordings and related review work sheets are prepared. A chart of the students' progress is displayed in the classroom. This is a motivating factor in keeping students up-to-date or even ahead of schedule.

It is a difficult procèss to group students in pairs, says Young (1972). The teacher must use all means available to determine each student's ability. Students are asked their first, second and third choice of partners. The most important thing, though, is that the students must be paired as closely as possible on ability or one may lean on the other.

The first day of class is spent explaining the procedures of the program. It is explained to students that they may talk quietly with their partner but they are discouraged from talking to other 
teams. They may work on daily assignments together or separately but they check their answers together.

In any class period a variety of activities will be going on. If partners are up-to-date on their work, they are free to do whatever they wish. Extra credit projects are available for students who want them.

Young (1972) feels there are many advantages to her program. The students can work at their own pace. There is greater teacherstudent contact because the lecture is eliminated. The use of the cassette recordings reinforces learning and assures the teacher a student is ready for a test. The quizzes are more meaningful because they act as a teaching tool as well as evaluation. The immediate correction of quizzes is appreciated and enables the students to get at misunderstandings fast. This type of quiz relieves tensions and anxieties in students. Since the students can work ahead, they get a chance to broaden their interest in math by selecting special topics.

\section{LEARNING FROM PEER TEACHERS}

This program in Drumright Elementary School in Oklahoma has some of the features of the Rancho Ca ̃̃ada program. In this program, however, students act more like tutors instead of equal working partners. Haun (1975) says that many programs across the 
country are recognizing how easily children learn from other children. More and more students are being assigned classroom instructional tasks with specific children as their responsibility. Haun states:

Teachers are constantly aware that some students in any class grasp certain new concepts quickly and are ready to move ahead, while others need to have some new material presented very slowly and with much repetition. Our program aims to take care of that repetition.

On a one-to-one basis, more capable students help those students having difficulties. This frees the classroom teacher to work with other students. A child might not be able to handle group of other children in an instructional setting, but on a one-toone basis they have found they make fine teachers. This extra attention that the learners receive helps them gain knowledge that must be grasped before the next concept will have real meaning. Haun (1975) believes, "The practice they give also helps their own learning. But perhaps more important is the sense of personal satisfaction that peer teachers gain."

\section{INDIVIDUALIZING BY GROUPS}

At the beginning of the year in this sixth grade program, a checkup was given over the fundamental processes. Using the test results, the students were grouped by needs. If one student only 
needed a short review, he was moved on quickly. If there was any lack of understanding it was carefully explained and the student did as much practice as he needed. Children who could use the fundamental processes, explains Graham (1972), worked on solving problems in area, volume and the metric system. They planned trips, made charts and graphs and solved a variety of written problems. A test was given every two weeks as a review of fundamentals to determine" needs for future grouping.

\section{WORKING AT AN INDIVIDUAL PACE THROUGH THE TEXTBOOK}

Individual Assignments Per Child In The Text

The students work through the textbook at a level of achievement that best suits their needs. During the first week of school the teacher attempts to find the level of achievement of each student. Each student is then given an initial as signment at the achievement level where he can work with understanding.

Each individual at a specific level of achievement is called to the teacher's desk. The teacher explains and illustrates the principles and procedures necessary to solve problems at this level. The student then works problems on the blackboard to show his knowledge and understanding. He is then given an assignment which does not go beyond the principles he has learned. If two or more 
individuals are at the same level, the teacher works with all of them together in the same way.

Keffer (1972) explains that during the regular class period the student works at the problems at a speed which he chooses until he completes the work or needs help. He keeps a notebook in which the problems are organized so that the teacher can spot-check them. From this spot-checking the teacher determines his progress, his understanding and where he needs more work.

When the teacher is not explaining a new process, she circulates among the students and checks their notebooks. Occasionally the entire class may be taught the same principle together, but only if all students have the background to understand what is being taught.

The teacher must be very familiar with several grade levels of math in order to help all students. It is necessary to have textbooks by several àuthors and publishers for each grade level. There needs to be continuous evaluation of student progress. Each student is also given a written test in problem-solving and computation at the end of each unit or chapter that he completes.

\section{Blackboard Appointment Approach}

To begin this individualized approach, Whitaker (1972) suggests placing the best students in individualized work first. This group may be given a long assignment to begin with as a review. As each 
child completes this assignment, he is placed in materials that match his achievement and then works individually. As soon as several children are working well at this program, the rest of the class may be gradually added to the program. It may take three weeks for the entire class to be working in this program. The slowest children will be the most difficult to start, says Whitaker (1972), because they will not have the security of the group. These children need reassurance. The arithmetic assignments should be made easy enough so they can achieve some success.

If a whole sixth grade class is put into this program, the range of learning may well be 3.6 to 7.6 . At the beginning there will be some confusion, but as the children realize they are learning at their own rate, the group relaxes and good learning takes place.

Each child has his assignment and a piece of graph paper. When he has finished the assignment he goes to the answer book and checks his answers. The score is plotted on the graph paper. Each error is analyzed by the child and, if he can, he writes why he missed the problem. When all of this is completed, he places his name on the appointment list on the blackboard. While waiting, he goes on with spelling, social studies, or other as signments.

The teacher, during the math period, takes the names from the appointment list for the child's individual conference. As the teacher checks the work, a new skill may be started, reinforcing 
drill assigned, or some type of enrichment given.

If a student finds he needs help during an assignment, he raises his hand to show he needs help immediately. The child with the raised hand is taken before the student on the appointment list. The teacher must know skills several grades above and below the grade level being taught. At times a group may be pulled together for instruction if they have the same needs.

\section{Blackboard Listed Assignments}

At the beginning of the year there is review and then the students are tested. The students then work at their own pace through the textbook. For example, on the first Monday, this assignment might be placed on the board: Page 32, examples $1-10$. Potamkin (1972) would tell her class, "When you have finished, bring your papers to me for checking." As soon as the first child had completed the assignment correctly, she placed a second assignment on the board: Page 34, top of page, rows 1-6. After students had completed the second assignment, a third as signment was placed on the board. Some students might still be working on the first. This meant that on Tuesday, she had to list all of the assignments from the beginning, to take care of the slower students, and keep adding new assignments for the more able learners.

Potamkin (1972) found that it was more efficient to ditto a list 
of assignments from the beginning of the unit of work and give a copy to each child. She listed only the textbook material she felt the students needed in working on a particular concept. Each student followed the list of assignments independently. Each step had to be checked and corrected before the next step could be attempted. She found she was swamped with papers so the students corrected their own.

\section{SEQUENTIAL LEARNING CONTRACTS}

Kramer (1972) describes the philosophy of his program:

Individualized instruction consists of planning and conducting with each student a program of studies that is tailored to his learning needs and his characteristics as a learner.

The program is organized through a series of sequential learning contracts. Each contract has a specific learning objective stated so the student knows what he must be able to do to demonstrate his learning. The contract tells what materials and procedures are required. The teacher is more of an educational consultant than an imparter of knowledge. The student works independently, asking for help from the teacher, when necessary. Each contract must be successfully completed before the student can progress to the next one.

If a student is absent he hasn't missed a vital part of an in- 
structional program. He simply picks up where he left off. All of the resources for learning are always available. This program can be school-wide so the next year the student can pick up where he finished the year before. There are no grade-level barriers. Kramer (1972) states, "The attitude each child has toward himself is improved because the program is built upon student successes rather than failures."

\section{TASK OR ASSIGNMENT CARDS}

Task or assignment cards are ideally suited for a math laboratory approach, say Reys and Post (1973). They also state, "Their ability to provide for individual differences is only limited by the variety of cards available."

Task cards vary in the complexity of assignments, but the format is the same. Three items are generally stated or implied:

1. Statement of problem or posing of question.

2. Identification of any necessary materials.

3. Special instructions, tables or graphs related to the task.

Task cards are preferable to paper because of their durability. If $4^{\prime \prime} \times 6^{\prime \prime}$ or $5^{\prime \prime} \times 7^{\prime \prime}$ cards are used, an index box may be used to store the cards. Some teachers prefer to have the cards displayed on a bulletin board or on a pocket chart. These cards may also be displayed on a table. 
Assignment cards may be oriented to the individual or to the group. The cards present problems and raise questions at various levels of sophistication. Cards for primary students or for poor readers may show the problem in pictures or with very few words.

How these cards are used in a class format varies, but they may replace the book in nearly any approach. They often provide more variety and interest, if done well and organized carefully. They lend themselves especially well to a learning center approach to teaching math.

\section{LEARNING CENTERS OR STATIONS}

\section{$\underline{\text { Definition }}$}

The use of learning centers is another method of individualizing learning. As Kaplan, et al, (1973) explains:

They provide a beginning point but are not intended to be the only source of individualizing instruction. Learning centers become the vehicles for moving students away from teacher dominated learning experiences and toward student-selected learning activities. Learning centers organize and direct learning experiences for students by allowing freedom while providing structure.

Godfrey (1973) explains that a learning station might be a fascinating corner, group of desks or table where children work together or alone in order to learn about a specific subject. A unit done by learning stations could include several centers that cover 
different aspects of the topic. These stations are not interesting centers for free-time activities. The materials and instructions are carefully planned so that children learn the basics at their own rate according to their own style. The students should feel comfortable and have choices. The steps at most stations are planned so that one builds on the next.

The teacher becomes free to be a resource person. The teacher can circulate around the room and give help whe re and when it is needed. As the children become more and more responsible for their own learning they become more and more independent. As Waynart and Wils on (1974) believe, "All teachers want students to know how to choose objectives, to select materials to meet those objectives, and to evaluate their own learning."

\section{Criteria For Success}

Hamilton and Fischer (1972) suggest that to set up successful learning centers, the following factors should be considered:

1. Centers should be accessible and well defined.

2. Experiences and activities must have a purpose.

3. Available tasks must be broad enough to interest children of varied abilities.

4. Additional tasks can be set up on a dayto-day basis depending on the direction the work is to go.

5. Keep some stable tasks and games at centers to provide for the security of the familiar. 
6. Motivate the use of the center by correlating it with the season, holiday or social sciences.

7. Be sure to take time to introduce new games and tasks to the group before placing them at the center.

8. Arrange materials so children can use them and put them back in an orderly fashion.

9. Don't move too fast, be consistent, be organized and be patient.

10. Trust children - they won't let you down!

The main characteristic of learning centers is that they

emphasize self-direction, say Waynant and Wilson (1974). Specific

characteristics that help a center foster self-direction are:

1. Clear directions

2. Clearly stated objectives

3. Choice

4. Multi-level activities

5. Answers

6. Manipulative as well as paper and pencil activities

7. Opportunities to work in small groups.

It is not necessary to provide for all of these characteristics at every learning center. However, the more that are included, the better the chances are that students will successfully move toward selfdirection.

Learning centers should have units that are open-ended so that no pupil will feel he has completed all the centers. The students should always be able to return to any center which particularly interests them. 
Teacher-Pupil Conferences

If a school or class is running a curriculum that is geared completely to learning centers, the teacher-pupil conference becomes the most important ingredient, says Olenzak (1973). The teacher's job at the se conferences is to help each child learn to set appropriate goals for himself. The student needs to be encouraged to live up to these goals and to learn to evaluate his own progress.

At the Llanerch Elementary School of Haverford Township near Philadelphia, Ms. Wright's class scheduled 15-minute conferences once a week with the teacher, explains Olenzak (1973). At this time they reviewed the previous week's activities. The pupil compared what he accomplished with what he had planned. He would go over his work folder and discuss what was easy and what was difficult for him. The rest of the conference was spent planning the next week's work. In this class, math had to be scheduled each day, but some subjects were given more flexibility. Besides individual instruction, some formal work was done with groups of the whole class.

Learning Center Example With A Measurement Unit

Godfrey (1973a) describes how a measurement unit was set up in a learning center's approach. The learning centers included several hands-on activities. This unit included three centers at which to work on three separate days during a one week period. Time was 
scheduled on three of the first four days and Friday was left for a free center period. The students could finish work not completed during the week on Friday. Each student kept a folder of his work for eventual evaluation.

\section{Conclusion}

The learning centers or stations approach provide an interesting way of teaching math. The approaches described here have followed these general characteristics, as outlined by Kidd (1970):

1. It relates learning to past experiences and provides new experiences when needed.

2. It provides interesting problems for the students to investigate.

3. It provides a non-threatening atmosphere conducive to learning.

4. It allows the student to take responsibility for his own learning and to progress at his own rate.

\section{COMPUTER-ASSISTED INSTRUCTION}

Some students receive their lessons on a teletypewriter terminal which is connected by telephone to a computer at the Stanford Computation Center. This program is for underachieving culturally deprived students. Patterson (1972) explains that there are five levels of difficulty for each lesson within a concept block. These drill-and-practice lessons are automatically presented, evaluated and scored by the computer. 
The twenty students share one teletypewriter and are scheduled so that they each work at it at least once a day during a two-hour interval. A new concept or idea is introduced by the teacher-coordinator before the student receives the lesson from the teletypewriter. The concept is usually taught the day before.

\section{INCIDENTAL APPROACH TO LEARNING MATH}

The incidental approach to teaching deepens the children's understanding of important concepts and makes the most of incidents that arise naturally during a school day, says Ebbeck (1974). He feels incidental learning is an especially important method in teaching the primary grades. He explains,

This approach is vital because it provides for the student an interesting and meaningful encounter with the unit concepts of a well-planned, sequential mathematics program not possible if the more contrived standardized approach is used unsupplemented.

Ebbeck (1974) feels that many of the commercially produced materials are well planned and can be used effectively as aids to learning. The teacher needs to use incidental happenings as a basis of curriculum design, but it cannot be haphazard. The teacher has a definite role in forming habits and structuring the environment for this kind of learning. The role of the teacher, according to Ebbeck (1974), includes at least the three basic responsibilities of 1) pro- 
viding materials, 2) becoming knowledgeable about mathematics, and 3) becoming more perceptive and responsive.

An imaginative teacher can make use of almost any situation to further mathematical knowledge. Ebbeck (1974) says that visitors to school, field trips, children's vacation, sports and cooking are just some ways that math can be incorporated into learning situations.

Each teacher's planning is very necessary, remarks Ebeck (1974). Based on her knowledge of the subject and the students being. taught, it must be determined what concepts and experiences should be introduced. The teacher will then be ready to put aside "regular" work to respond to the interests of the individual and the moment. Concept-laden incidents will arise many times during the school day. Hilton (1973) feels that the teacher must take cues from the students. They can tell the teacher how much they need to know and to organize and develop strategies for a successful program. The teacher is still the key, but learning can be stimulated through children's interests.

\section{STUDENTS CHOOSE INTERESTING MATH TOPICS}

Junior High Approach

The students selected their own assignment level. They were also given the opportunity to enrich the class program, states Snyder (1972), with a part-time independent study of another topic. In fact, 
students were encouraged to do this.

\section{Scheduling Optional Activities}

The students were permitted to explore areas of mathematics that interested them. Scanlon (1972) explained that half of the class time scheduled for math was set aside for students to study an area other than that assigned by the teacher. The optional area of math was selected from one of the twelve units of the math continuum used in the school. After completing a unit of work, students were allowed to change their area of study.

\section{Strand Approach}

The students in this fourth grade, under the direction of the University of Wisconsin, could select not only the topics they chose to study but also the materials they wished to use in working with these topics.

Eight strand booklets were put together which covered all major fourth grade concepts. It was necessary that each strand included its own prerequisite concepts so that no one strand would have to come before any other. Bartel (1972) says that it was the general rule that within a strand, the material would proceed from the simpler concepts to the more complex topics, if distinctions could be made for that unit.

The eight strands included in the project were: sets, geometry, 
numeration, rational numbers, problem solving, measurement, addition-subtraction and multiplication-division.

To help students find references on a chosen topic, the math books in the class library were coded according to publisher and grade level with heavy felt pen markings.

Whenever it was appropriate, each topic within a strand began with references from third grade texts and went through sixth grade texts. Not all topics were covered by this range of grades, so it was used only where possible.

The students were given a copy of each strand booklet. A chart of numbered spaces was stapled in the left cover, When a student felt he had completed the topic to his satisfaction he would color in the space which contained the topic number. A color code was used to show the date and sequencing to topics. Stapled to the right side of the folder were eight sheets which corresponded to the eight strands of the project. On each sheet was a list and order of topics included in the strand. It was this list the student used in choosing a strand, level or topic on which to work.

The students did all of their computations, correction and scoring on worksheets that were made available. The worksheets were kept in the folder and used as a basis for the teacher-pupil conferences. 


\section{STUDENTS CHOOSE THEIR OWN PROGRAM}

Littledale (1973) feels that teachers should still teach students, to a degree, but that it is inefficient for the teacher to do all of the teaching. That way the teacher becomes a bottleneck. Littledale (1973) states:

I think you have to start off with the assumption that the most efficient kind of education permits any student at any time to have access to any material and human resources - hardware and software, teachers, teacher aids, other students, outsiders and so on - he required in order to learn what he needs to learn... Any resource at any time for any student - this would mean that you would put a premium on physical flexibility.

Littledale (1973) thinks that each child should go through a curriculum which nobody can predict because it is his own, drawn from his own needs and developed according to his unique capacities. The student should control the sequence. He feels it is posible because there are many ways of reaching the same main learning goals. It doesn't matter which way a child travels as long as he gets there. Littledale (1973) feels that if you truly individualize in this way,

You get something that looks like open education. But whatever it looks like, it means that the kids are doing what they want and need to do at the right time and in an order and a manner, in a medium and a mode that makes sense for that kid at that time.

At Robinwood Elementary School in Franklin, Wisconsin, 
students choose their own program. Ziegler (1974) describes

Robinwood Elementary School's indicators of individualization:

1. Students are pursuing individual learning objectives.

2. Each student is aware of his own personal learning needs.

3. Students are working independently or in small groups.

4. Students select from a variety of print and non-print materials to accomplish learning tasks.

5. Studènts set their own goals.

6. Students monitor their own progress.

When each student works on his own program, in his own way, and at his own rate; a highly individualized form of learning is taking place.

\section{SUMMARY}

Criteria were presented to help the reader evaluate individualized approaches to math instruction. Eleven categories of individualized math programs were described in detail. These programs are being used, or could be used, in elementary schools in the United States.

Team learning involves having a partnership arrangement where two students work together at the best pace for the two of them. Peer teachers are used on a one-to-one basis to give some students extra practice. Some students are grouped by need and 
the group works on subjects they need. Working at an individual pace through the textbook is another form of individualizing. Some students work on sequential learning packets which cover specific learning areas.

Task cards provide for individual differences by varying in complexity, subject and format. Task cards can be used effectively in a learning center approach to instruction. Learning centers are interesting areas in the class which offer a variety of activities and are organized to help the student develop self-direction. Computers are now assisting some learners by providing drill and practice within concept blocks. The incidental approach to math teaching involves making the most of incidents which a rise naturally during the school day.

Some students are given the chance to work on math projects of their choosing, in addition to their regular math assignments. Other students are given complete freedom to determine their own math program and monitor their own progress.

Regardless of the approach to individualizing, a sensitive and humane teacher is necessary. As Hunter (1973) says, the school environment should be organized so individual growth is facilitated. The environment should encourage self-direction. Flexibility is needed for on-the-spot modifications. This concern for the individual learner is needed in math, as well as in all subjects. 


\section{CHAPTER V}

\section{A ROTATING SYSTEM OF MATH EDUCATION}

This chapter will deal with how a rotating system of math education works for the sixth grade team at Mooberry Elementary School in Hillsboro, Oregon. Beginning the chapter will be a description of the town of Hillsboro and Mooberry School. Background will be given on why this team switched from ability grouped math instruction to a rotating system. The district adopted math textbook will be analyzed and the task cards, which replaced the book, will be described.

The day-to-day operations of the class will be discussed in detail, beginning with how the school year is started. A general description of the program and the system of rotation will be included. A typical math period will be explained. Student helpers are needed in the program and their jobs will be discussed, with emphasis on how the students' work is checked. The recording of students' progress for the teacher will be described, as will the methods of reporting pupil progress to parents. A chapter summary will end the selection. 


\section{HILLSBORO, OREGON}

Hillsboro, Oregon is located eighteen miles west of Portland in the beautiful and fertile Tualatin Valley. It is the county seat of Washington County, one of the fastest growing areas in Oregon. The town is sixty miles from the coastal beaches and ninety minutes from the recreational areas of the Cascade Mountains. The Chamber of Commerce in Hillsboro describes this city of 18,800 as:

Hillsboro is a fun (sic) town in which to live, with adequate recreation available in the form of bowling alleys, theatres, public swimming pool, tennis courts, numerous ball parks and several beautiful and spacious city parks. Five first class golf courses are available in just minutes from the city. There are several streams for fishing in season in the valley. The city is a well-planned city in which to live, play, work, and also to educate your children. Many new building areas are available.

For years Hillsboro derived most of its income from agriculture. Much of the farmland is now going to sub-divisions and many of the older farmers are moving to town. The city has a high proportion of elderly people, due to this shift in occupations. Many residents of Hillsboro now work at the Tektronix plant in neighboring Beaverton. Many of these Tektronix jobs required well-educated personnel, which contributes to a more highly educated population in Hillsboro. Other people work seasonally at the Bird's Eye cannery in Hillsboro. The cannery and farms in the area attract much seasonal labor. Special 
migrant programs are set up in several schools which have the highest concentrations of transient families. A sizeable number of Hillsboro residents are employed by the Port of Portland because the back-up airport for the Portland International Airport is located. at Hillsboro. This airport is currently being expanded. There are many smaller businesses in the area, too.

Hillsboro is in the midst of drawing up a land-use plan to conform to the state's land use goals. Questions are being asked about how to keep Hillsboro from blending into the neighboring town of Beaverton, and how much good farmland should be taken up with housing and roads. The town has a great deal of community spirit and can surely work out some of these problems. Recently, though, the city has had trouble passing its budgets, but it did vote for a new city library.

\section{MOOBERRY ELEMENTARY SCHOOL}

Hillsboro is divided into elementary and secondary school districts. In the Hillsboro Elementary District \#7 there are six schools. Students from kindergarten through sixth grade attend the se schools.

The rotating system of individualized math is in operation at Mooberry Elementary School, located at N.E. 10th and Arrington. There are three classes of each grade, with about thirty students per 
class, making the total enrollment around 530. The district classroom average is supposed to be twenty-four, but several housing projects in the Mooberry attendance area are causing a squeeze in the enrollment. The Mooberry attendance area draws from some very affluent subdivisions, some new modest subdivisions, much rural land and several new apartment complexes.

Three of the elementary buildings are termed "open" in physical structure. Mooberry was the first of these "open" buildings to be constructed in Hillsboro. Three classrooms open together in each grade level, with sliding doors between each room. Each grade level in the building uses its "openness" in a different way. In the sixth grade team, the teachers feel there is a time to have all of the students together in a group of ninety and there are other times when groups of thirty are more manageable. The doors are opened and closed depending on the noise and nature of the activity. The basic floorplan of Mooberry School sixth grade team is shown in Figure I.

\section{FIGURE I}

\section{BASIC FLOORPLAN OF MOOBERRY SCHOOL. SIXTH GRADE}

\begin{tabular}{|c|c|c|}
\multirow{2}{*}{ Franklin } & \multicolumn{3}{|c|}{ Helpingstine } & Hatch \\
\cline { 3 - 3 } & $6 \mathrm{~B}$ & $6 \mathrm{~A}$ \\
& & \\
& &
\end{tabular}


There are three teachers in the sixth grade team. The teachers are Mrs. Kathy Franklin, Mr. Jim Helpingstine and the writer of this paper, Miss Lynda Hatch. The team has no clearly designated team leader. The teachers are in their middle twenties and early thirties, spanning about eight years in age.

The teachers strongly believe in the rights and responsibilities of each child. Individual work is combined with group projects throughout the daily subjects. Attention is given as to what types of assignments are best for each child.

The principal, Mr. Ron Stewart, is very helpful and supportive of teachers'ideas and projects. He believes in treating children as respected individuals. He makes Mooberry School an enjoyable and satisfying place to work. The superintendent, Mr. Alton O. Smedstad, knows all of the teachers on a first-name basis. He knows each teacher's programs and approaches with children. When the teachers at Mooberry have a new idea, like the rotating math system, it is welcomed, as long as it proves to be a good learning experience for children.

\section{BACKGROUND}

The sixth grade team began searching for a way to individualize their math classes. The first year they had been together, the math classes were ability grouped. The teachers were not pleased with the 
system because so many students felt defeated and "locked in" to a class. The teachers worked hard on the improvement of self-concept and enjoyment of math that year, but just couldn't go through another year using that approach. Jones and Pingry (1972) also believe that many people are opposed to the homogeneous grouping of students within a grade level. People feel that it is not possible, that it is not democratic and that it is hard on a student's mental health.

The teachers spent the summer of 1973 looking for a different approach to math education. The next fall they put their ideas together and developed their rotating system, which will be described in this chapter.

\section{DISTRICT-ADOPTED MATH TEXTBOOK}

The district adopted math textbook, Modern Mathematics Through Discovery (1970) from the Silver Burdett Company, has not pleased the writer of this paper. Frustrations have been felt with the large amount of reading used in the examples. Students who have difficulty in reading should not be punished in math for this reading disability. Barney (1972) feels that many students who appear to have a dislike for math actually have a reading problem associated with math, and not mathematics per se.

In the opinion of the writer, the book offered too many ways to approach a problem when many students needed to learn one basic 
way thoroughly. This was especially true with students who had difficulty in math. The book tended to introduce a subject with a great deal of reading, show several ways to approach the problems, give little practice and quickly move on to another concept. However, when this book was adopted for the Hillsboro Elementary District \#?, it was chosen above others which offered less practice.

The other two teachers in the team developed their math units on an individual basís like the writer, but each varied his approach considerably. The other teachers basically used a listing of assignments out of the textbook, though a variety of materials has been added lately. For the purpose of this chapter, only the methods of the writer will be discussed.

\section{TASK CARDS}

The writer felt a combination of many books and games, plus her own ideas, would make a more substantial and enjoyable program than the adopted text. During her first year at Mooberry, she had quickly changed from the book to dittoed worksheets. With these worksheets as a basis, she put together task cards. Many more cards were developed and games were collected to form a good sequence of learning. The materials for the program were gathered and organized over a three-year period. In an effort to have the best task cards possible, an extensive collection of books, manipulative devices 
and games were compiled. Below is a partial list of the many books used in the design of this rotating program:

Allen, Chuck, Daily Chores in Mathematics, Palo Alto, California; Creative Publications, Inc., 1972

Cech, Joseph P. and Joseph B. Tate, Geo-Board Activity Sheets, Oak Lawn, Illinois, Ideal School Supply Company, 1971

Haugaard, James C. and David W. Horlock, Fun and Games With Mathematics, Los Gatos, California, Contemporary Ideas, 1972

Horne, Sylvia, Patterns and Puzzles In Mathematics, Pasadena Calif., Franklin Publications, 1968

Kelley, S. Jeanne, Learning Mathematics Through Activities, Cupertino, California, James E. Freel \& Associates, Inc., 1973

Laycock, Mary and William T. Stokes, Math Activity Worksheet Masters, Palo Alto, California, Creative Publications Inc., 1971

Schadler, Reuben A. and Dale G. Seymour, Pic-A-Puzzle, Palo Alto, California, Creative Publications, 1970

Schreiner, Nikki Bryson, Games and Aids For Teaching Math, Hayward, California, Activity Resources Company, 1972

Seymour, Dale and Mary Laycock and Verda Holmberg, Aftermath 1-4 Series, Palo Alto, California, Creative Publications, 1971

The cards were kept small and covered only one, or a very few, concepts. The more advanced the units were, the more advanced the concepts and reading became on the cards. The writer would rather have a student accomplish several smaller cards than drag on through one large one. 
Each unit has been color coded to make the organization easier. The problems were written for the task cards and then mounted on the appropriate colored construction paper. For example, the division unit was divided into three parts: 1) One digit division, 2) two digit division, and 3) division review. The first unit was mounted on salmon colored paper, the second on yellow paper, and the third on green. A small picture of part of a comic was attached to the card to add a bit of color, interest and variety. A sample copy of a task card from the one digit division unit is found in Figure II.

The titles of the cards were written or underlined in red. These titles must be written on the student's paper because that is the only identification the card has. 'No page or row numbers can be referred to, like would be possible from a textbook. A numbering system has not been devised because that would make the program less flexible for future change. Without numbers, cards can be added or eliminated at any time without destroying the numbering system.

At least five of each card were made so that several students could work on a card at once. The cards have been laminated for longer use. The proper care of the cards is discussed with the students. The cards have not been allowed to leave the classroom because trying that on an experimental basis did not prove successful. The cards got crumpled in desks and were sometimes lost. The cards take too long to make and cost too much to have laminated to be 


\section{FIGURE II}

ONE DIGIT DIVISION UNIT SAMPLE TASK CARD

One Digit Divisors with Remainders
1. $4 \longdiv { 1 7 }$
2. $3 \longdiv { 2 2 }$
3. $5 \longdiv { 2 1 }$
4. $8 \longdiv { 6 5 }$
5. $9 \longdiv { 5 5 }$
6. $8 \longdiv { 4 3 }$
7. $4 \longdiv { 3 9 }$
8. $3 \longdiv { 2 8 }$
9. $9 \longdiv { 1 9 }$
10. $9 \longdiv { 7 3 }$
11. $2 \longdiv { 9 }$
12. $6 \longdiv { 3 5 }$

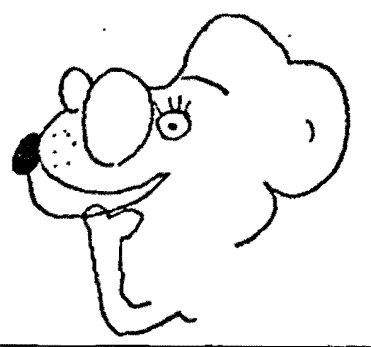


constantly replaced.

The cards have been stored in labeled envelopes. The envelopes and game pieces for each part of the unit were put in one box. For example, in the division unit, all of the envelopes containing salmon cards (one digit divisors) were put in one box. All yellow cards were in one box and all green cards were in another. Then, all three division boxes, plus any materials which would not fit in the boxes, have been stored together on shelves. One corner of the classroom has been organized for the storing of these math materials.

\section{STARTING THE SCHOOL YEAR}

At the beginning of the year, the basic operations of whole numbers are reviewed in homeroom classes. After two or three weeks when the students seem comfortable with math after the summer "lapse", the students are given a diagnostic placement test. The test is constructed by the teachers in the team. Each teacher writes the section of the test which covers the part he teaches in the rotation.

Using this test and a student-teacher conference, a decision is made where each student will begin the year for math instruction.

\section{SYSTEM OF ROTATION}

The rotating math system is individualized in the sense that the 
students work at their own pace. A sequence of skills has been established through which the students work. Below is an outline of the sequence of skills which are taught:

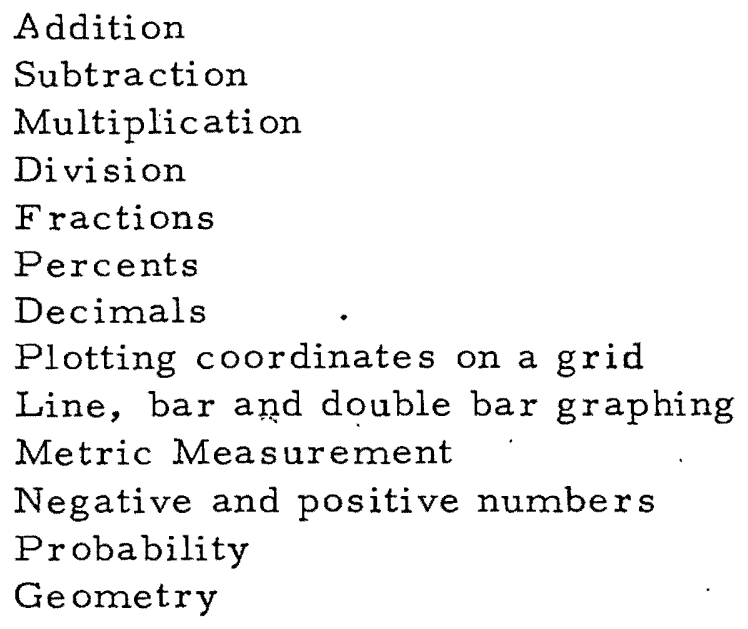

Each teacher starts the year with what might traditionally be looked at as high, medium and low groups. One teacher begins at the low end with students who need work in addition, subtraction.and multiplication. The writer takes the students who need work in division. The third teacher has the most advanced students, who need work on fractions. At this time of year, most students could use some work on fractions, so these three groups cover the students quite well.

The rotating system varies somewhat from year to year because of the needs of the students. For example, if a large number of students needed work in multiplication, a separate multiplying class can be set up. However, the sequence of skills remains the same.

Each teacher has a different approach with the subject matter and the students. Regardless of the approach, when the teacher feels 
the student has reached an acceptable competence in that subject, the student is rotated into the next class. The students move individually, not as a group.

A teacher could get over-burdened with students if careful coordination among the teachers is not done. It is important at the beginning of the year to make sure the three groups that start the cycle are divided evenly, even if it means changing teacher roles. Some years it may be necessary to have the three starting classes be addition, subtraction and multiplication. Other years there may not need to be any of these three classes.

Once the cycle is underway, if it looks as if a teacher will be receiving too many students, alternative approaches to teaching may be needed. The teachers must sometimes change their unit goals. They may find they are expecting too much of the students and need to change the assignments so the students are successful and the rotating system works. At times, some students may physically work in another room, different from their step in the cycle, if crowding is temporary. No students should have their progress held up because the teacher has not planned well. If the teachers plan together and keep communication open, over-burdening is not a serious problem.

The system of rotation will now be described in detail. A diagram of the rotation is found at the end of this section. A student in multiplication would move into division and a student in division 
would move into fractions. A student who had finished fractions would go into the room where multiplication was still being taught, only this student would begin a program of percents and decimals. It makes little difference that two quite different. subjects are being taught at the same time. All of the work is at the student's own pace and is done by himself or in small groups. If the teacher has the materials and lessons prepared in advance, there is no problem having two sets of instruction happening at once.

When students have completed percents and decimals, they rotate into the class on plotting coordinates on a grid and graphing. There will be students working on division, but they can help each other in many ways, plus they enjoy seeing the variety of things that happen in math. These graphing students then rotate into a metrịc measurement class where fraction students are still working. After. metric measurement they go back to the class where multiplication, decimals and percents are being taught. There they are introduced to positive and negative numbers and also to probability. From probability they rotate into geometry. The geometry unit is extensive, to provide much enrichment and enjoyment of math concepts. No student has ever rotated past this point, but if a student would be ready, additional units could be set up.

Some students do not need every class and may skip a section or have limited review. It often happens, for example, that a student 
needs review with borrowing in subtraction, but then skips multiplication and division and begins again with fractions. The program is very flexible. A diagram that should make the rotating system more clear is portrayed in Figure III.

\section{A TYPICAL MATH PERIOD}

The students attend math for 45 minutes each day in the morning. They find a place to sit (there is no assigned seating chart) and wait for their booklet to be passed back to them by one of the students. They receive any papers they turned in the day before. They put these papers inside the brads in the back of their booklet.

The student then checks the list of task cards in his booklet to see what card he needs next. He goes up to the math corner and. requests the card from the two student helpers. One of the helpers gets the card and the other records what card and possibly what game pieces are being checked out. It became necessary to have the students keep careful records of who checked out which materials to prevent loss.

The student then takes his card back to his seat and completes the work. If he has a question he comes to the teacher or to another student who could help him, and then continues to work. Waynant and Wilson (1974) approve of the students becoming free in their learning. Students become free of constant supervision so the teacher is also 


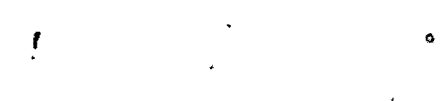

FIGURE III

DIAGRAM OF MATH ROTATING SYSTEM

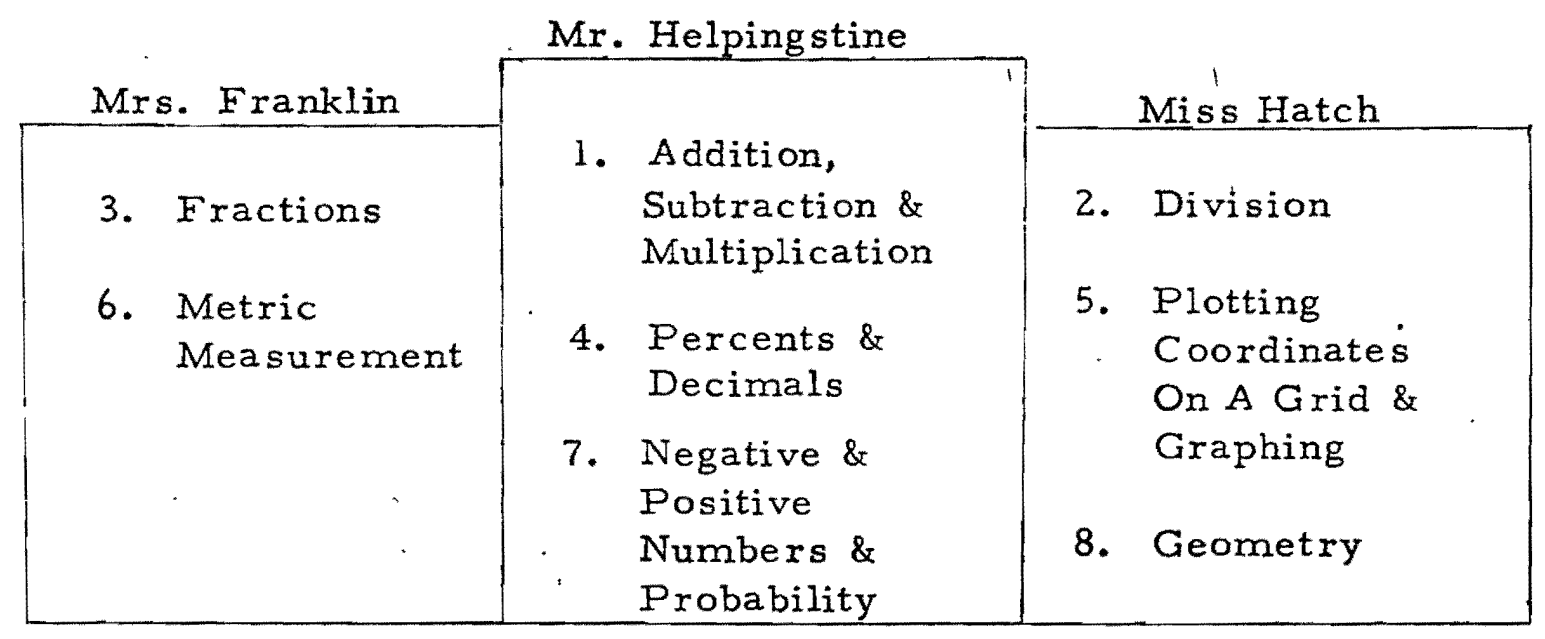


free. The teacher can use this freedom to work with any student who needs individual attention.

When the student has completed the card, he writes the completion date in his booklet, turns his paper in to make sure the name is crossed off the list so the student is not responsible for any materials. He checks out the next card if time allows.

At the end of the math period, the student turns in his booklet to a box on the counter. He only turns in his booklet if he has a new paper in it that was corrected the day before, but not recorded by the teacher in his booklet. Other students, without new papers, take the booklets back to their homeroom.

\section{CHECKING THE STUDENTS' WORK}

The student corrector first passes back all papers that were checked the day before. He then checks all papers except for the geometry papers, which are more difficult to check because of the advanced concepts. The teacher checks the geometry papers.

Answer books have been made out of photo albums with "magnetized" plastic. These are quite sturdy and the plastic keeps the cards from smudging. The answers have been color-coded on cards, by unit, to help the corrector. For example, answer to the one-digit division papers have been mounted on salmon paper in the photo album. 
At the end of the math period, the student corrector gives the teacher a pile of corrected papers and possibly another pile of some that have not been corrected.

\section{STUDENT HELPERS}

The corrector is just one of several student jobs. The students help with the jobs that are needed, in order to make the system work. They keep their job for a week. It is arranged so each student works on at least one job while he is in the class. Each week the student is a helper, he writes down the dates in the appropriate space in his booklet. That way, the teacher can remember the job he did and not think he made no progress for a week. Each Monday new helpers are chosen, usually by asking who hasn't done the job and would like to do

it. The main student jobs are:

1. One corrector

2. Two students who pass out the task cards

3. One student who passes back the student booklets at the start of each period.

The student helpers are trained by the students who had the jobs the previous week. The teacher usually gives additional suggestions to the corrector because it is a more complicated job. The students handle their jobs quite well. Occasionally, a student needs extra directions on how to do the job, but he is never removed from a job. Each student is trusted to do his best job possible. 
The students who are helpers usually have quite a bit of time to work on their own math. There are breaks between students needing cards and the corrector often has no papers to check at the start of the period.

Having these jobs in the class helps the students with their own math, too. The corrector often becomes more conscious of neatriess and getting the proper heading on for the corrector. The people who pass out the cards and booklets learn patience and organization.

\section{RECORDING STUDENTS' PROGRESS}

After math, the teacher quickly goes over the papers that were checked. These papers are recorded in the grade book devised for this program. No grades are given on the papers, just as fraction of the number correct. For example, 12/13 would mean that the student got twelve correct out of the thirteen problems. All games done with the right procedure receive "OK."

In the grade book is listed all the assignments and their point value. A sample of a grade book recording sheet from the one-digit division unit is shown in Figure IV. The grade book sheets are on dittoed paper with color-coded construction paper dividers between the units.

On the ditto is a space for the name of the student and then a box for each task card of the unit. In the box the teacher writes the 
FIGURE IV

SAMPLE OF GRADE BOOK RECORDING SHEET

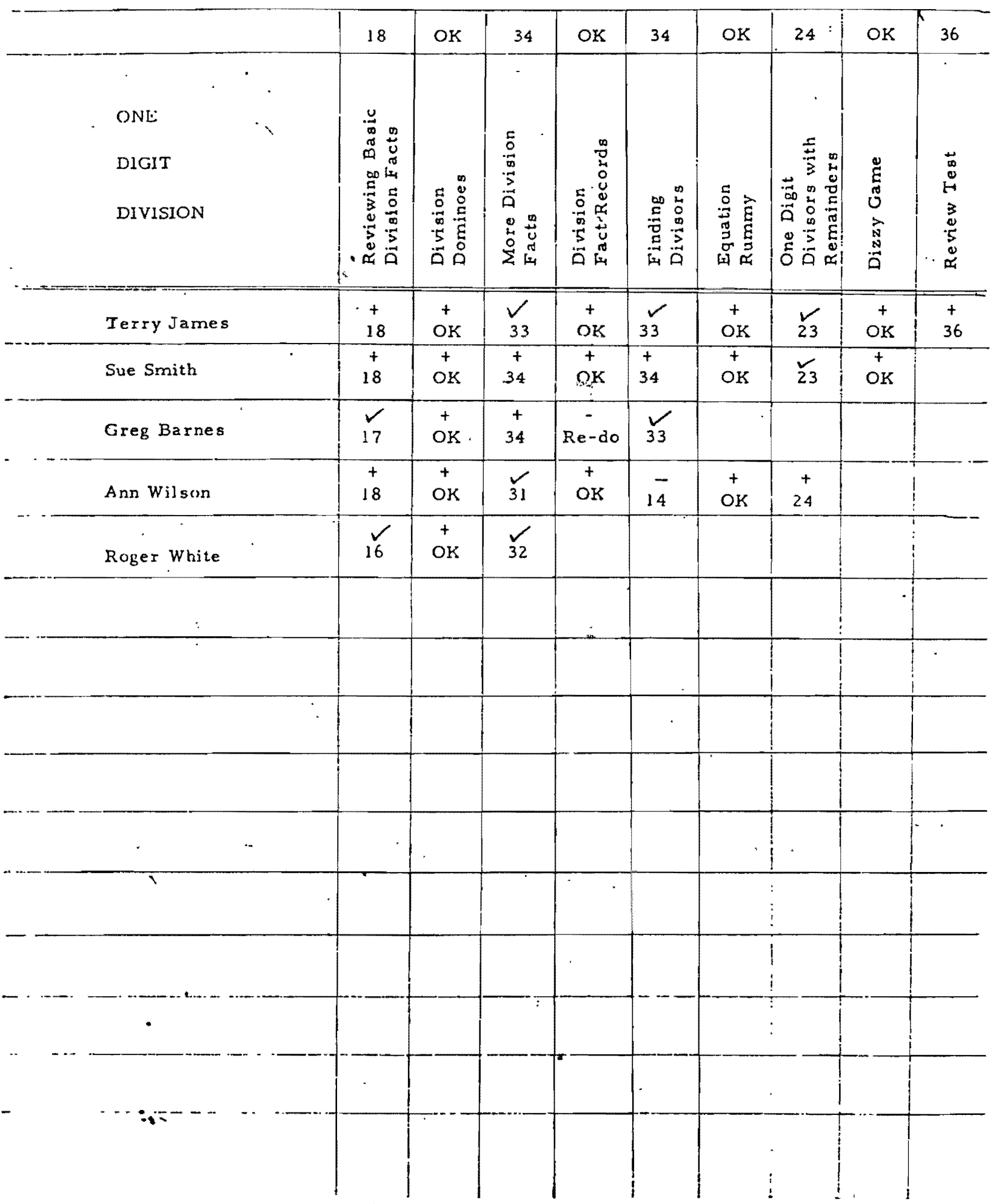


number of problems the student got correct. Above that score a + is written if the student got the paper all correct, a $\checkmark$ if the student got between half right and one wrong, and a - if the student got less than half right. This,$+ \checkmark$, and - system is helpful when quickly reviewing how a student is doing. The teacher can glance across the page and see if there is a majority of $t^{\prime} s, V^{\prime} s$, or -'s. If a student receives a majority of $V^{\prime}$ 's or ${ }^{-1} s$, he is probably going a bit too fast or is careless.

If the student should miss over half of the problems on a card, he must re-do a paper. This is usually if he is missing the same concept in several problems, even if he got over half right. Perhaps he failed to bring up a zero in the answers of four division problems. It would be important enough for him to discover the pattern of his error.

The cards take small enough steps so that most students are able to get many papers done perfectly, although the goal is definitely not perfection for every student.

After recording the scores in the grade book from the papers turned in that day, the teacher goes through the student booklets. These booklets hold all of the papers for the unit. The score is recorded from the new papers in the booklet and the teacher initials the appropriate column.

On the student's assignment page in his booklet, there is the 
name of the assignment, a space where the student colored in the card color of the unit (for organizational purposes), a space where the student wrote the date he finished the paper, a column for the teacher to write the fractional number correct, and a column for the teacher to sign his initials. It became necessary for the teacher to initial the page to guarantee that all students were completing the work under the guidance of the teacher. A sample of a student's one-digit division unit assignment sheet from his booklet is shown in Figure V.

\section{REPÓRTING TO PARENTS}

There are two types of report cards used in the Hillsboro Elementary District \#7. The parents have a choice of the narrative form of the checklist/grade form. It would be very time-consuming to write narratives to describe the progress of so many children. On the graded form it would be frustrating because the teacher could not tell enough and a grade would be arbitrary when the student works for himself and does not compete with the class. These limitations led the teachers to develop their own math reporting form. The teachers made a list of all classes offered in the rotating cycle, described the class, named the teacher for each section, made a column to check which parts of the cycle the child had already finished, left a place to indicate where the student was currently working and made a place for narrative comments. An example of the math form used for reporting progress to parents is shown in Figure VI. 
FIGURE V

STUDENT ASSIGNMENT SHEET

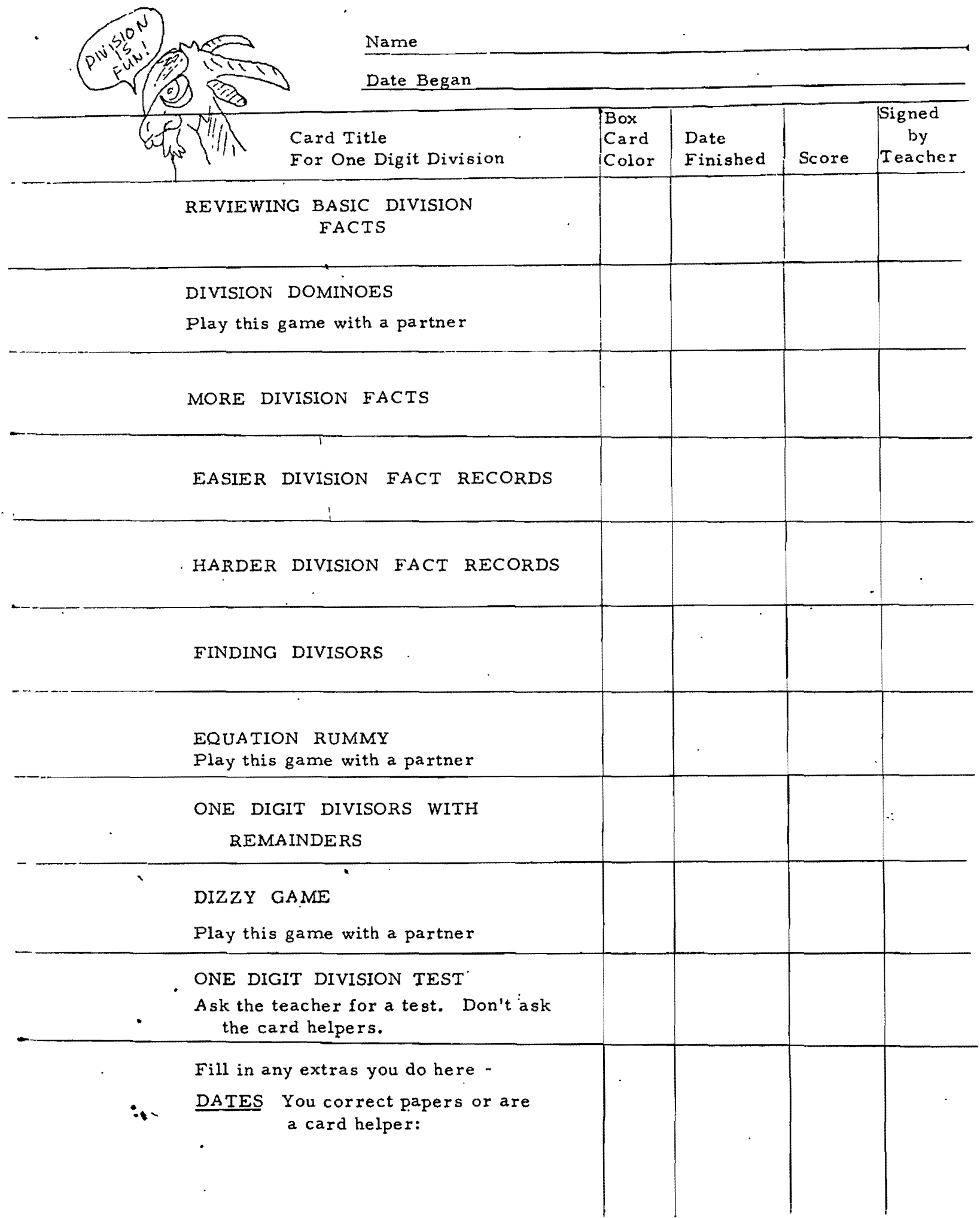




\section{FIGURE VI}

\section{MATH REPORT CARD}

\section{FALL MATH REPORT FOR MOOBERRY SIXTH GRADERS}

In the 6 th grade tean, the students work at their own pace. They rotate through

the three rooms on an individual basis. The students began at a level in the rotation cycle wich would help them the most.

\begin{tabular}{|c|c|c|c|}
\hline DONE & WORKING & TEACHER & CLASS DESCRIPTION \\
\hline & & $\begin{array}{r}\text { Helpingstine } \\
\text {. }\end{array}$ & $\begin{array}{l}\text { This unit began with a review of adding and subtracting. } \\
\text { The multiplication unit follows, including multiplication } \\
\text { of whole numbers. }\end{array}$ \\
\hline & . & Hatch & $\begin{array}{l}\text { The division unit is made up of three parts: } \\
\text { One digit division and multiplication check } \\
\text { Two digit division and multiplication check } \\
\text { Division review with more difficult problems. }\end{array}$ \\
\hline & $\cdot$ & Franklin & $\begin{array}{l}\text { The fraction unit includes addition, subtraction, nulti- } \\
\text { plication and division of proper and improper fractions. } \\
\text { Can find common denominators for unlike fractions } \\
\text { Can add like fractions } \\
\text { Can add unlike fractions } \\
\text { Can subtract like fractions } \\
\text { Can subtract unlike fractions } \\
\text { Can multiply fractions } \\
\text { Candivide fractions }\end{array}$ \\
\hline
\end{tabular}

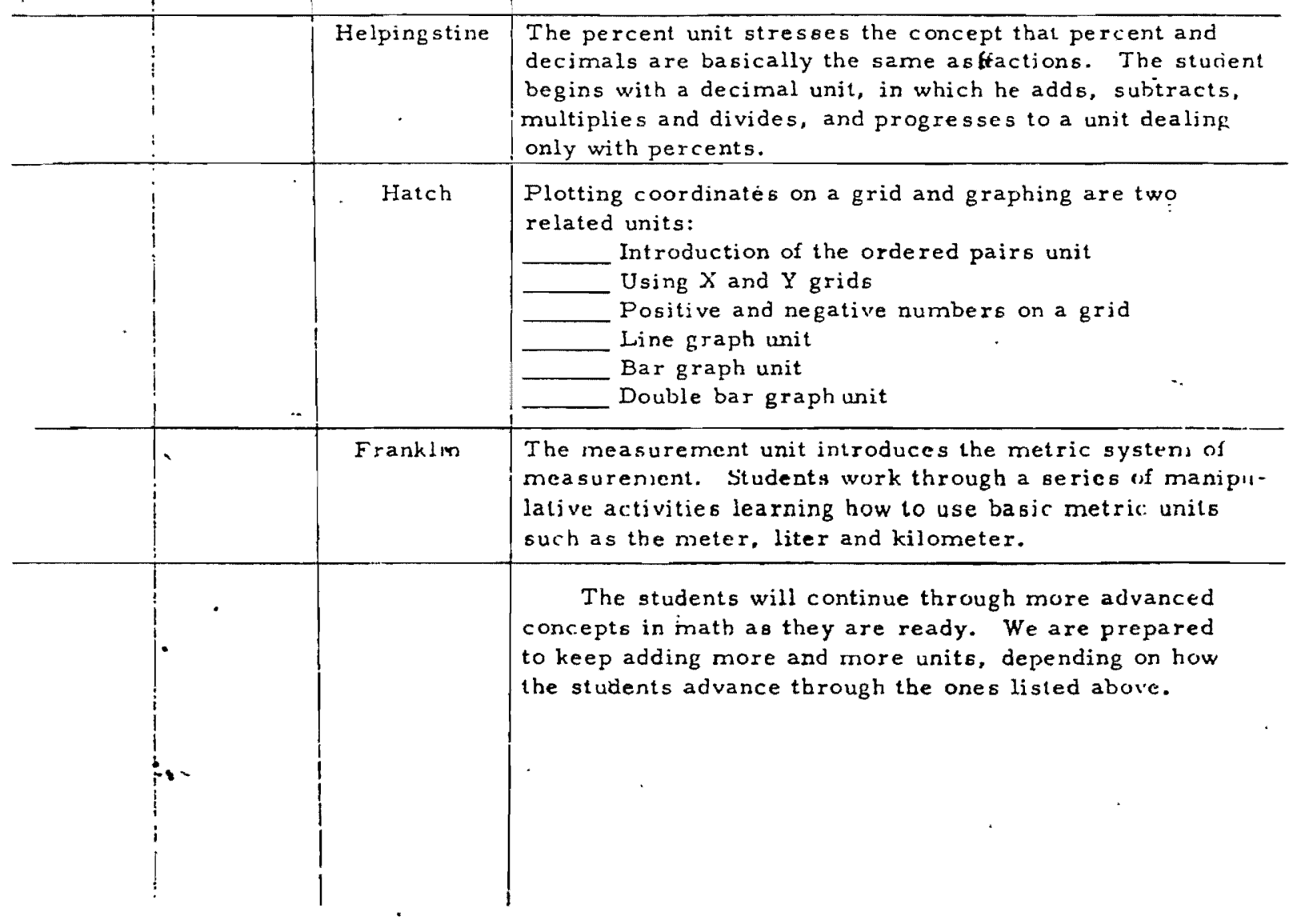


This reporting form gave the parents, child and homeroom teacher a fairly detailed picture of the student's progress and current level in math. For parents who wanted this information, the teachers arbitrarily said that students in addition, subtraction, multiplication and division were generally working below grade level for sixth grade. Those students in fractions, percents and decimals could be considered on grade level. The students in plotting coordinates on a grid and beyond, were working ahead of average sixth graders. The grade levels were not played up too much, but served as a handy guide for most parents.

Most students did not seem to be working toward "grade level" accomplishments, but were working because they enjoyed what they were doing. This was certainly a refreshing change from the old. "high, medium and low" groups where many students felt they were as good as "stuck" for the year.

It's hard to say exactly how many classes the average student rotated through in a year. Some students started at a point where they only needed review before rotating and others had much more work to do at their beginning unit. Most students felt successful if they rotated through three classes, although some accomplished a great deal more and some worked more slowly. Most classes took about two months to complete. Some classes took longer for some students, depending on the student's background and interest in the 
subject.

The teachers have received a great deal of thanks from parents who appreciated the large amount of information on their child at reporting times. Report cards certainly did not tell the full story, though. A more complete story was told when the student shared his booklet with his parents. Usually the student was very proud of his work. All of his papers were together and he could clearly see his progress. There was something special about having all of the papers together in a purposeful booklet, rather than just having them stuffed in a desk. All of the booklets, throughout the team, were saved to go home at report-card time. Parents and students were encouraged to take time to share the child's school progress.

\section{SUMMARY}

A rotating system of instruction is just one approach teachers can use to individualize their math class. This rotating system is working in the sixth grade team at Mooberry School in Hillsboro, Oregon. The system was started when the teachers decided ability grouping, which had been in effect, was not the most beneficial system for their students.

This rotating system is individualized in that each student works at his own pace through a flexible sequence of skills. A different math skill is taught in each of the three rooms. The student 
rotates through the rooms individually, as the teacher feels the student has attained competence. Each of the three teachers is responsible for teaching two or three units within the cycle. Only the writer's responsibilities were described in detail.

The textbook has been eliminated from the instruction and has been replaced by task cards. The task cards cover a variety of problem cards and games. Student booklets, answer books in photo albums, grade books and report cards have been devised to fit the program. Students help with the jobs in class. The student jobs help the class run smoothly and help the students gain in organization and responsibility.

The rotating system at Mooberry School is just one approach to individualizing math instruction. 
CHAPTER VI

\section{EVALUATION OF MOOBERRY SCHOOL'S ROTATING MATH PROGRAM}

The sixth grade teachers at Mooberry School felt pleased that they could set up an individualized, rotating math program for their students. The teachers then looked for evidence of success by continually appraising the program. Informal and subjective information was collected, such as notes on student work habits, skills and attitudes. Questionnaires were used to collect more formal data. The questionnaires were devised by the Mooberry teachers and the Educational Development Center. The program was also evaluated by the Mooberry School principal, Mr. Ron Stewart. Eventually, the teachers would like the program to be evaluated in a more thorough and valid manner to test its superiority over other programs.

\section{1973-74 MULTIPLE CHOICE EVALUATION}

A survey was given to the sixth grade team at Mooberry School on May 29, 1974, at the end of the 1973-74 school year, to evaluate the Man: A Course Of Study social studies program. This survey, by the Educational Development Center, had been used in the early field 
testing of the Man: A Course Of Study program. The Hillsboro Elementary District \#7 used the survey as an evaluation of how the sixth graders reacted to the social studies program, but it also evaluated math instruction. The survey had no official title. The survey asked for student opinions about Man: A Course Of Study and about preferred methods of learning.

\section{Social Studies Questionnaire}

The first half of the survey was strictly on social studies evaluation, using a multiple choice format. For example, Part II, question \#7 asked:

While studying about Netsilik Eskimos, I like to work best:

(Check 1 answer)

alone
with one friend
with the teacher's help
in a small group
in one big group (with the whole class)

\section{Math Questionnaire}

The second half of the questionnaire related the study of social studies to the study of math. The math data will be discussed, since it is the part relevant to this chapter. All questions asked about math were asked in an identical way about social studies. No comparison between the two courses was asked for, except at the end, when comparing four subjects in question \#5. On the questions the students 
were to put an " $\mathrm{X}$ " in the box under the heading which best answered the question. All data is from all three sixth grade classes.

\section{Ability In Math}

The students were asked how they rated their ability in math compared to those in their class at school:

$\begin{array}{ccccc}\begin{array}{c}\text { Among the } \\ \text { Poorest }\end{array} & \begin{array}{c}\text { Below } \\ \text { Average }\end{array} & \begin{array}{c}\text { Average } \\ \text { Average }\end{array} & \begin{array}{c}\text { Among the } \\ \text { Best }\end{array} \\ 3 \% & 8 \% & 45 \% & 28 \% & 16 \%\end{array}$

The responses to this first question showed that $89 \%$ of the students felt they were average or above in their math ability. Close to a majority of students felt their ability in math was above average or better.

High School Graduation Position

The students were asked where they thought they would be in their high school graduating class in mathematics:

$\begin{array}{ccccc}\begin{array}{c}\text { Among the } \\ \text { Poorest }\end{array} & \begin{array}{c}\text { Below } \\ \text { Average }\end{array} & \begin{array}{c}\text { Average } \\ \text { Average }\end{array} & \begin{array}{c}\text { Among the } \\ \text { Best }\end{array} \\ 2 \% & 0 \% & 26 \% & 46 \% & 26 \%\end{array}$

The results of this data show that $98 \%$ of the students thought they would be average or above in their high school graduating class. A majority of students $(72 \%)$ thought they would be above average or better. 


\section{Students Grading Themselves}

The third question asked the students to forget for a moment that others graded their work. They were to tell, in their opinion, how well they do their math:

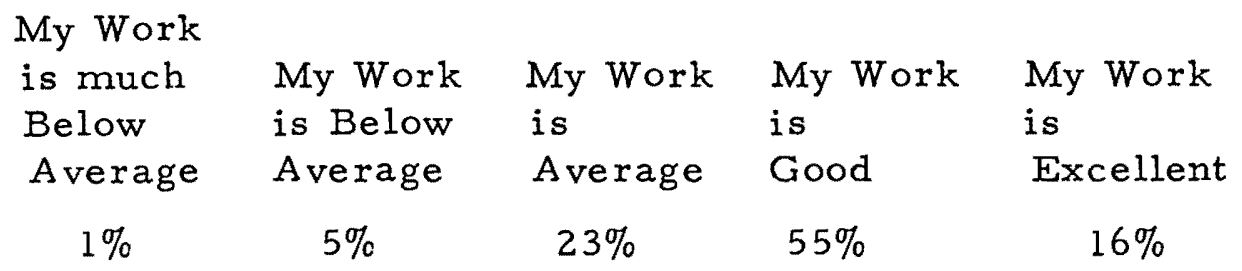

The results of this question show that $94 \%$ of the students felt the quality of their math was average or above. A majority of students ( $71 \%)$ felt they were above average in math quality.

\section{Grade Capabilities}

The fourth question asked the students what kind of grades they thought they were capable of getting in math:

\begin{tabular}{|c|c|c|c|c|}
\hline Mostly & Mostly & Mostly & Mostly & Mostly the \\
\hline Poor & Below & Average & Good & Highest \\
\hline $\begin{array}{l}\text { Grades } \\
\left(F^{\prime} s\right)\end{array}$ & $\begin{array}{l}\text { Average } \\
\text { Grades } \\
\left(D^{\prime} s\right)\end{array}$ & $\begin{array}{l}\text { Grades } \\
\left(C^{\prime} s\right)\end{array}$ & $\begin{array}{l}\text { Grades } \\
\left(B^{\prime} s\right)\end{array}$ & $\begin{array}{l}\text { Grades } \\
\left(A^{\prime} s\right)\end{array}$ \\
\hline $0 \%$ & $0 \%$ & $12 \%$ & $48 \%$ & $40 \%$ \\
\hline
\end{tabular}

The responses to this question showed that $100 \%$ of the students felt they were capable of earning grades which were average or better. A sizeable majority of students $(88 \%)$ felt they were capable of better than average grades. 
Favorite Subjects

The fifth question the students were asked to indicate how well they liked these four school subjects: English, math, science, and social studies. The students were given a list of the subjects. They were to place a "l" after the subject they liked best, a " 2 " after the subject they liked the second best, a " 3 " after the subject they liked third best and a "4" after the subject they liked the least.

The results of the question showed that math came out as the favorite subject, receiving $53 \%$ of the vote. The break-down of the subjects was as follows:

$\begin{array}{ll}\text { Math: } & 53 \% \\ \text { Science: } & 25 \% \\ \text { Social Studies: } & 11 \% \\ \text { English: } & 11 \%\end{array}$

When the students' first two favorite subjects were tallied and added together, math still came out the leader, receiving $40 \%$ of the vote.

Interpretation:

Although this survey was used as a tool for evaluating the Man: A Course of Study social studies program, the math results are useful. The results show the success in positive self-concept and enjoyment the Mooberry sixth graders have toward their math instruction: They generally felt their ability was high, they would graduate in good standing in their high school class, they deserved good grades on their math, and they felt they were capable of getting good math 
grades. The majority of students chose math as their favorite subject in school.

\section{1974-75 NARRATIVE EVALUATION}

On June 6, 1975, at the end of the 1974-75 school year, the students in the writer's homeroom, evaluated the math program; as well as the other aspects of the school year. The students were asked to respond in a narrative manner to each of the school subject areas and also to the numerous activities and field trips of the year. The students were given a dittoed list of the subjects and activities. The following are typical comments about the rotating math program.

They include all of the major points made by the students:

"This year's math was really neat. You don't have to wait and be held back and wait for the other guy to catch up. This way you can work on your own pace and I think that it's funner!"

"This year's math was a new concept. I enjoyed it." "I think the math system is great."

"I liked math a lot and moved much more than I thought I could."

"It was fun. I think I worked pretty hard."

"Math was very good except the math books. Some people could not get out of the math book but when they did get through to your class it was easy as ABC."

"This year for me, math was really neat. I liked going from room to room because it made me really think I was making progress. I learned a lot this year in math. 
I feel that you had the best set-up in it and I learned the most in here. I only wish. I could have finished the geometry unit."

"It gave me a chance to relax while doing math." "The way you did it was very neat. I enjoyed it." "At first I hated math 'cause I didn't know how to do it but now I realize I can and I love it."

"I had fun in plotting, metric and geometry. With the other rooms sometimes I was bored to death. I think that the rotation is best because some people are ready for harder work."

\section{PARENT RESPONSE}

The parents of Mooberry sixth graders have repeatedly congratulated the teachers on their approach to math instruction. The parents have received a great deal of information at conference time about their children and have expressed appreciation for the detailed reports. Many parents have found that their children are now coming home and talking about math class. The parents have been pleased that their children have received a strong basic approach in the fundamental operations of math and are pleased that competence is stressed.

The parents are often surprised that their children will bring math home to work on, all on their own, since no homework is . assigned. Parents have explained that they are now working much more closely with their children on math. The children are eager to 
show they are learning, instead of asking for help over textbook misunderstandings. Parents repeatedly ask the sixth grade teachers to recommend their child for the one and only class at the junior high that allows the students to progress at their own rate.

\section{EVALUATION BY THE PRINCIPAL}

The principal of Mooberry School, Mr. Ron Stewart, wrote an evaluation of the rotating math instruction, specifically for this chapter. The evaluation is in the form of a letter to the writer:

July, 1975

Lynda Hatch,

In response to your request for a personal informal evaluation of the math program you have developed and used during the past two years, I am pleased to make several points based upon my own observations of the program in operation in your classroom.

From my point of view, I would emphasize, first, the value of the program for individualizing instruction. Based on the premise that each student has his own learning style and rate of speed, the use of this program, in my judgment, has successfully permitted the students to progress at their own rate and perhaps to enjoy math more at the same time.

Secondly, I would refer to the flexibility of this program. In my view, one of its major strengths is that it is not a self-limiting program. Each unit is set up to provide certain required work, some "extra" or optional exercises, and always it is clear that the possibility exists to go beyond what the unit has to offer. This permits the flexibility of using a wide variety of outside materials, whether they be drawn from adopted texts, formal supplementary materials, or creative ideas of teachers and students. 
Finally, in the absence of any formal data comparing this program with any other, I would make the following observations:

A. I discussed with you and read some of the results of a questionnaire in which students rated math at the top of a list of school subjects, as they evaluated the year.

B. I would emphasize one important advantage of the choice of materials for this program. They were creatively chosen and organized, and the high student interest was evident during my classroom observations. The materials were the source of frequent favorable student comments during my observations.

C. The program is organized so that students seem to have a good sense of direction as they are given responsibility for record keeping, and charting their own progress through the units.

D. The program is effedtive in serving the needs of both the accellerated student and the slow-learner.

E. I am particularly impressed with the built-in provisions for close teacher supervision of individual progress. This offers balance to the program, and keeps the teacher close to the instructional needs of the students.

In my judgment the program is good enough to warrant setting up a control group and making a real effort to test its superiority over programs being used in our school or elsewhere in the district.

Mr. Ron Stewart

Principal of Mooberry School

\section{METRO MATH TEST RESULTS}

The Metro Math Test, developed by the Metropolitan Area

Testing Program Board, was given to Mooberry sixth graders only in the fall, on October 10, 1974. Therefore, the scores do not show a 
progress report. The scores may give the reader a better understanding of the Mooberry attendance area, however.

The average total on the math scores was 52.33 standard scoring. As shown by Tables I and II, Mooberry students tended to score above average for the Portland Metropolitan area. Mr. George Anderson, Director of Measurement for the Washington County Intermediate Education District, says that it has been proven that students in the Portland Metropolitan area test above the national norms. These test results show Mooberry sixth graders to be capable learners.

\section{TABLE I}

\section{FREQUENCY GRAPH}

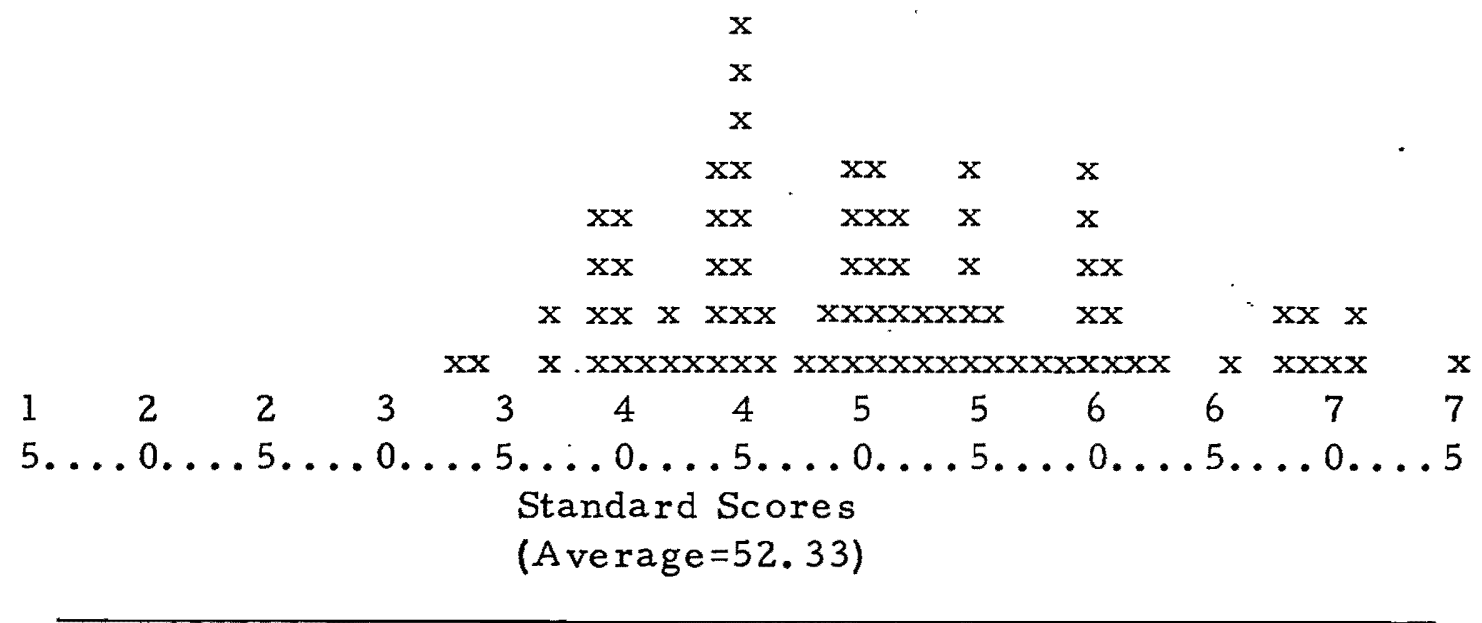


TABLE II

DISTRIBUTION BY ADJECTIVE DESCRIPTION

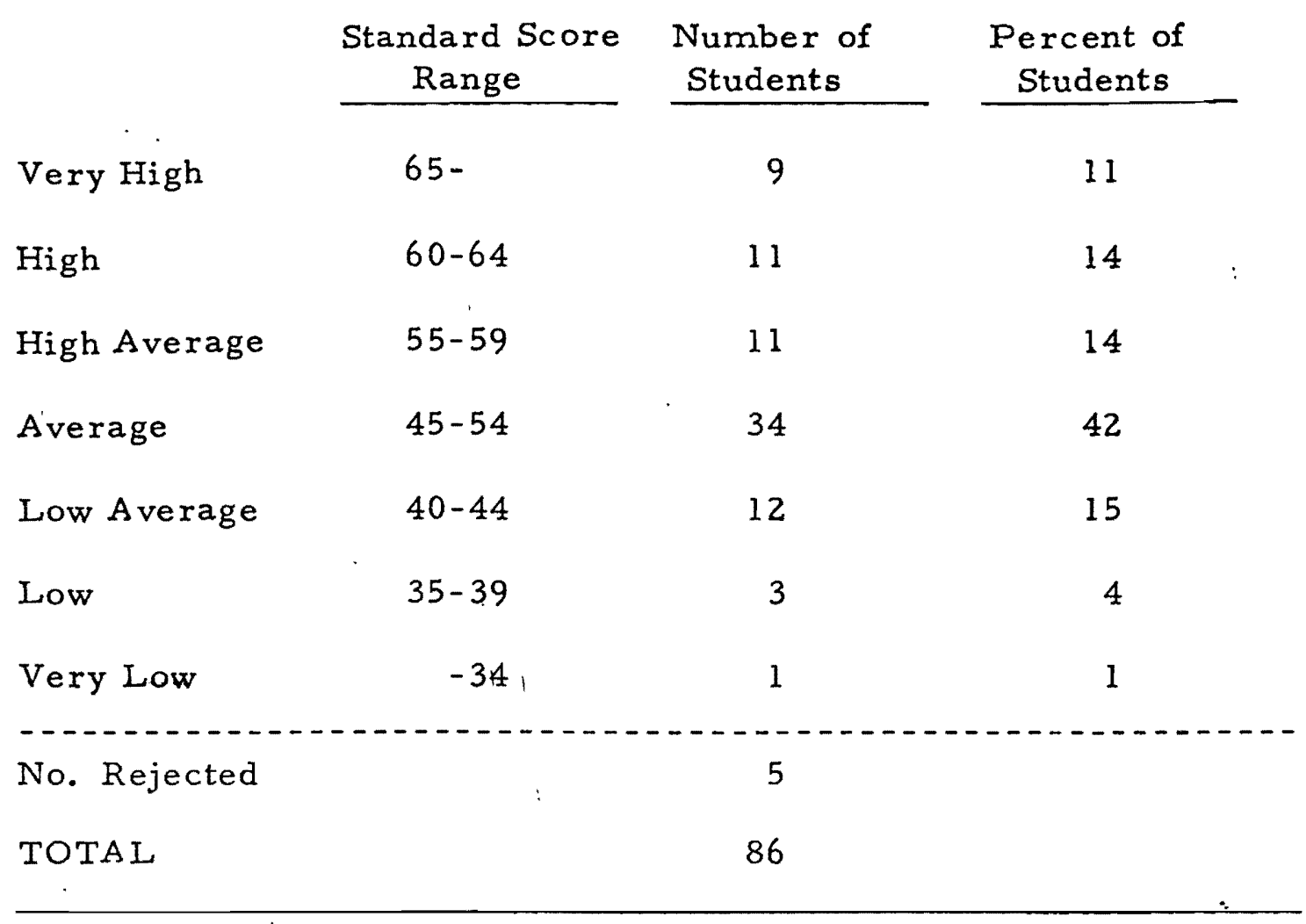

SUMMARY

The sixth grade teachers at Mooberry School felt pleased that they were able to set up a successful math program that has been approved of by students and parents. The teachers have been encouraged because they have seen the students making great strides in skills and self-confidence in math. The students expressed their confidence in math in both the 1973-74 survey by the Educational Development Center and the narrative form from the 1974-75 school 
year. The students indicated how well they enjoyed the math classes at Mooberry in question \#5 of the Educational Development Center survey, as well as on the narrative comments from 1974-75. The principal of the school, Mr. Ron Stewart, expressed his confidence with the program.

Mooberry School sixth graders, who tested out above average for the Portland metropolitan area in math skills, found this rotational program to be enjoyable and to increase their skill and confidence in mathematics. 


\section{CHAPTER VII}

\section{CONCLUSION}

Recent trends in math education in the United States have been discussed. The most recent and humane trend seems to be that of individualized instruction. Examples of the most common and useful individualized math programs in recent years have been described. These programs have been organized into eleven general categories.

A rotating system of math instruction was described, as it works for the sixth grade team at Mooberry School in Hillsboro, Oregon.

The program has demonstrated that a team of three sixth grade teachers, working and planning together, can design a rotational math program. The teachers can prepare the materials and implement the program successfully. The program is one that children enjoy and one in which they make mathematical progress.

There are questions which should be considered about this rotational math program. How can the schedule be arranged so that all students get a sample of a wide variety of math experiences, since they don't have time to rotate through all of the classes in a year? Is this approach to math the best experience for these students since 
they will be placed in a "traditional" program in junior high? What are the best ways to motivate the very few students who don't use their time well and don't progress as far as they could for their ability? What should happen when a student decides he won't work for a certain teacher, yet the child needs the skill that teacher is covering? How can one team of teachers help another team see that there might be a more humane and effective way to handle students, especially in math?

There will continue to be questions raised. As they are raised and answered, the rotating math program will change to meet these needs. This rotating system works well in Mooberry School. It can be used in other schools, if it is the best program to fit the needs of that school.

Hunter (1973) feels that, "Seldom is the ideal of 1) just the right task, 2) the right learner behavior and 3) the right teacher behavior perfectly achieved." Individualized math instruction involves careful teacher decision-making to come close to this ideal.

Individualized math programs are just one part of making the whole learning experience of the child a happy and successful one. 


\section{BIBLIOGRAPHY}

Arnold, Danie 1S. and Audrey Boodloe. "How To Innovate Successfully," Today's Education, Vol. 63 No. 1, Jan-Feb 1974, pp. $62-66$.

Ashby, Deborah H., "Children Need to be Treated as Individuals," Instructor, Vol. LXXXIV No. 1, Aug. /Sept. 1974, pp. 23-24

Barney, Leroy. "Problems Associated With the Reading of Arithmetic," The Arithmetic Teacher, Vol. 19 No. 2, Feb. 1972, pp. 131-133.

Bartel, Elaine V. "Individualized Instruction in Elementary School Mathematics, "Individualized Instruction in Mathematics, Metuchen, New Jersey, The Scarecrow Press, Inc., 1972, pp. $132-138$.

Bezuszka, StanleyJ. "A New Level of Excitement and Insight," Learning Magazine, Vol. 3 No. 7, March 1975, pp. 28-35.

Botts, Robert E., "The Climate for Individualized Instruction in the Classroom, " in Individualized Instruction in Mathematics, Metuchen, New Jersey, The Scarecrow Press, Inc., 1972, pp. $406-408$.

Chilcote, Elinor and Jeannie Blaine and Nancy Nason. "Happy Time Mathematics, "The Arithmetic Teachers, Vol. 11, No. 2, Feb. 1975, p. 140 .

Cohl, Claudia, ed. "Turning on to Math," Teacher, Vol. 92 No. 2, Oct. 1974, pp. $24 \& 26$.

Davis, Robert B. "New Math Success/Failure?" Instructor, Vol. LXXXII No. 6, Feb. 1974, pp. 54-55.

Denman, Theresa. "Mathematical Hyacinths," Instructor, Vol. LXXXII No. 8, April 1973, pp. 68-69.

Denman, Theresa, "Math Games For Fun... and Learning, " Instructox, Vol. LXXXII No. 6, Feb. 1973, p. 76.

Denman, Theresa. "What's With Ratio?" Instructor, Vol. LXXXII No. 6, April 1974, pp. 42-44. 
Deturk, Philip. "Give Children Lead Roles," Instructor, Vol. LXXXII No. 6, Feb. 1973, pp. 48-49.

Ebbeck, Frederick. "How Billy's Bag of Candy Taught Kids to Count to Ten, "Instructor, Vol. LXXXII No. 6, March 1974, pp. 92 \& 94.

Ebeid, William T. "Self-Selection and the Teaching of Mathematics," in Individualized Instruction in Mathematics, Metuchen, New Jersey, The Scarecrow Press, Inc., 1972, pp. 302-328.

Fisher, Victor L., Jr. "Merits of Selected Aspects of Individualized Instruction, " in Individualized Instruction in Mathe matics, Metuchen, New Jersey, The Scarecrow Press, Inc., 1972, pp. 229-235.

Found, Helen S. "Openness is a State of Mind," Instructor, Vol. LXXXII No. 8, April 1975, p. 18.

Galton, Grace K. "Indivualized Instruction: Speaking from Reality," The Arithmetic Teacher, Vol. 19 No. 1, Jan. 1972, pp. 23-25.

Geiser, Robert L. "If I'm Not at the Center of Things - Where am I?" Ieacher, Vol. 91 No. 6, Feb. 1974, pp. 18, 22, 27.

Gibb, E. Glenadine. "Through the Years: Individualizing Instruction in Mathematics," The Arithmetic Teacher, Vol. 17 No. 5, May 1970, pp: 396-401.

Gillett, Thomas D. "Teachers Can Make Changes," Ioday's Education, Vol. 62 No. 4, April 1973, pp. 44-45.

Godfrey, Lorraine Lunt. "Measurement - The Learning Stations Way," Ieacher, Vol. 91 No. 1, Sept. 1973a, pp. 68 \& 78.

Godfrey, Lorraine Lunt, "Learning Stations - Why and How," Teacher, Vol. 91 No. 1, Sept. 1973b, pp. 6.0-61.

Graham, Evelyne M. "Individualized Instruction: Distinguishing Characteristics," The Arithmetic Teacher, Vol. 19 No. 1, January 1972a, pp. 13-15.

Graham, William A. "Individualized Teaching of Fifth-and SixthGrade Arithmetic," in Individualized Instruction in Mathematics Metuchen, New Jersey, The Scarecrow Press, Inc., 1972, pp. 235-7. 
Hamilton, Virginia and Charlotte Fischer. Discover New Ways... Centers, Tasks, Games, Hillsborough, California, Hillsborough School District, 1972.

Haun, David. "Where Kids Teach Kids," Teacher, Vol. 92 No. 7, March 1975, pp. 59-60.

Henderson, George L. "Individualized Instruction: Developing Broadened Perspectives," The Arithmetic Teacher, Vol. 19 No. 1, Jan. 1972, pp. 7-12.

Herald, Persis J. "Helping the Child Who Can't Do Math, "Teacher, Vol. 91 No. 7, March 1974, pp. 46-47, 89.

Hilton, Ernest. "Individualizing - Take Your Cues From Kids," Instructor, Vol. LXXXII No. 6, Feb. 1973, pp. 43-44.

Hoffman, Ruth I. "Learning Through Games," Instructor, Vol. LXXXIV No. 2, Oct. 1974, pp. 69-70.

Holt, John. How Children Fail, New York, 'Dell Publishing Co., Inc., 1964.

Holt, John. What do I do Monday? New York, Dell Publishing Co., 1970.

Hunter, Madeline. "Review," Instructor, Vol. LXXXII No. 6, Feb. 1973, p. 54.

Jones, R. Stewart and Robert E. Pingry. "Individual Differences," in Individualized Instruction in Mathematics, Metuchen, New Jersey, The Scarecrow Press, Inc. 1972, p. 379.

Kaplan, Abraham. "Achieving Individualized Instruction," in Individualized Instruction in Mathematics, Metuchen, New Jersey, The Scarecrow Press, Inc., 1972, pp. 119-124.

Kaplan, Sandra Nin and Joan Ann Butom Kaplan and Sheila Junishima Madsen and Bette K. Taylor. Change for Children, Pacific Palisades, California, Goodyear Publishing Co., Inc., 1973.

Keffer, Eugene R. "Individualizing Arithmetic-Teaching, " in Individualized Instruction in Mathematics, Metuchen, New Jersey, The Scarecrow Press, Inc., 1972, pp. 172-175. 
Kerr, Donald R. "Mathematics Games in the Classroom," The Arithmetic Teacher, March 1974, Vol. 21 No. 3, pp. 172-175.

Kidd, Kenneth P., and Shirley S. Myers and Davis M. Cilley. The Laboratory Approach to Mathematics, Chicago, Science Research Associates, Inc. 1970.

Kohl, Herbert R. "Begin Where the Students Are At ... But Where Are They?". Teacher, Vol. 9I, No. 4, Dec. 1973, pp. 36-37.

Kohl, Herbert R. Math, Writing and Games: The Open Classroom, New York, Vintage Books, 1974.

Kramer, William R. "Borel Individualized System of Instruction," in Individualized Instruction in Mathematics, Metuchen, New Jersey, The Scarecrow Press, Inc., 1972, pp. 328-347.

Littledale, Harold, ed. "Managing a Child-Centered Curriculum," Teacher, Vol. 91 No. 1, Sept. '1973, pp. 21-22, 24, 28, 32.

Moustakas, Clark. Teaching As Learning, New York, Ballantine Books, 1959.

McBreath, Marcia. "Teachers Who Individualize," Today's Education, Vol. 62 No. 4, April 1973, p. 43.

Niman, John. "Probability and Statistics," Instructor, Vol. LXXXIV No. 5, January 1975 , p. 52.

Odom, Jeffrey V. "The Metric System - Learn It! Think It! Teach It!" Instructor, Vol. LXXXIII No. 2, Oct. 1973, p. 60

Olenzak, Karen Romnes. "Learning Centers - The Teaching Approach that Makes Old Schools Like New," Teacher, Vol. 90 No. 6; Feb. 1973, pp. 54-57.

Patterson, Marian J. "Computer-Assisted Instruction of Underachieving Culturally Deprived Students," in Individualized Instruction in Mathematics, Metuchen, New Jersey, The Scarecrow Press, Inc., 1972, pp. 169-172.

Perry, E. L., Jr. "Integrating Geometry and Arithmetic," The Arithmetic Teacher, Vol. 20 No. 8, Dec. 1973, pp. 657-662. 
Potamkin, Caroline C. "Experiment in Individualized A rithmetic," in Individualized Instruction in Mathematics, Metuchen, New Jersey, The Scarecrow Press, Inc., 1972, pp. 128-247.

Redbird, Helen. "Individualizing Arithmetic Instruction," in Individualized Instruction in Mathematics, Metuchen, New Jersey, The Scarecrow Press, Inc., 1972, pp. 126-128.

Reys, Robert E., and Thomas R. Post. The Mathematics Laboratory - Theory to Practice, Boston, Prindle, Weber \& Schmidt, Inc., 1973.

Scanlon, Robert G. "A Program for Encouraging Self-Initiated Activities," in Individualized Instruction in Mathematics, Metuchen, New Jersey, The Scarecrow Press, Inc., 1972, pp. $251-74$.

Snyder, Henry D., Jr. "Two Self-Selective Approaches in Junior High School Mathematics, "in Individualized Instruction in Mathematics, Metuchen, New Jerșey, The Scarecrow Press, Inc., 1972, pp. 328-347.

Spaulding, Robert L. "Personalized Education in Southside School," in Individualized Instruction in Mathematics, Metuchen, New Jersey, The Scarecrow Press, Inc., 1972, pp. 39-48.

Swadener, Marc. "Pictures, Graphs and Transformations - Distorted View of Plane Figures for Middle Grades," The Arithmetic Teacher, Vol. 21 No. 5, pp. 383-389.

Timmer, H. Joann. "Make Way for the Right Math," Teacher, Vol. 91 No. 9, May/June 1974, pp. 12, 14, 16.

Trafton, Paul R. "Individualized Instruction: Developing Broadened Perspectives," The Arithmetic Teacher, Vol. 19 No. 1, J̀an. 1972, pp. 7-12.

Ward, Beatrice. "Four Major Issues in Mathematics Instruction," in Teaching Mathematics in the Elementary School - What's Needed? What's Happening? Washington, D.C., National Association of Elementary School Principals, National Education Association and the National Council of Teachers of Mathẹmatics, 1970, pp. 27-37. 
Waynant, Louise P., and Robert M. Wilson. Learning Centers... A Guide for Effective Use, Paoli, Pa., The Instructo Corp., 1974.

Wegener, Dallas D. "Individualized Instruction - Who Needs It?" The Arithmetic Teacher, May 1972, Vol. 19 No. 5, pp. 355-57.

Whitaker, Walter L. "Individualized Arithmetic - An Idea to Improve the Traditional Arithmetic Program, " in Individualized Instruction in Mathematics, Metuchen, New Jersey, The Scarecrow Press, Inc., 1972, pp. 128-131.

Young, Carolyn. "Team Learning," The Arithmetic Teacher, Vol. 19 No. 8, Dec..1972, pp. 630-634.

Ziegler, Roger J. "Innovation: Checking out Instructional Change," Teacher, Vol. 91 No. 5, Jan. 1974, pp. 38-39. 


\section{APPENDIX A}

\section{DIVISION UNIT TASK CARD DETAILS}

\section{One Digit Division}

1. Reviewing basic division facts

Basic division problems are given which show the relationship between multiplication and division.

2. Division Dominoes

This is a game with a partner to review basic division facts.

3. More division facts

Basic division facts are given, with no remainders.

4. Division fact records

Basic division facts are given on a record, three seconds apart.

5. Finding divisors

Easy division problems without remainders are given, with the divisors missing but the answer is given.

Plus, a section is given on matching division and multiplication pairs.

6. Equation Rummy

This is a card game with a partner, dealing with logic. It also reviews the basic operations of addition, subtraction, multiplication and division.

7. One digit divisors with remainders

Single digit divisors with remainders a re given.

8. Dizzy

This is a game, played with a partner, to review the basic division concepts which have been presented in the unit.

9. One digit division test

This test is a review of the one digit division section. 
Two Digit Division

1. Two digit divisors

Two digit division problems are given, such as $2 4 \longdiv { 7 8 }$.

2. Checking two digit divisors

Two digit division problems are given, such as $1 4 \longdiv { 1 7 6 }$.

Two problems must also be checked by multiplying.

3. Practice with two place divisors

Practice problems are given with dividing with two digit

divisors and checking half of the problems.

4. Equation Fish

This is a card game with a partner, dealing with logic.

It also reviews the basic operations of addition, subtraction, multiplication and division.

5. Longer steps with two place division

1 Division problems are given which require bringing down a number for the first time, such as $2 2 \longdiv { 9 0 2 }$

6. Two digit division game

This is a game, played with a partner, to review the two digit division concepts which have been presented in the unit.

7. Dividing with money

Students are given two digit division problems which require them to include dollar signs and decimals points in the answers. The problems are checked by multiplying.

8. Stamina

This game is played alone. It reviews the operations of addition, subtraction, multiplication and division.

9. Finding averages

Problems are given in finding averages.

10. Division football game

This game is played with a partner and reviews all two digit division concepts which have been presented in the unit.

11. Two digit division test

This test is a review of the two digit division section. 


\section{Division Review}

1. Mixed practice

Problems are given which review computation in addition, subtraction, multiplication and division.

2. Equation Solitaire

This game is played alone. The game deals with logic and also reviews addition, subtraction, multiplication and division.

3. Division review A

Review is given on one digit division problems.

4. Division review $B$

This card reviews two digit division problems.

5. Number Scramble

This game can be played alone or with a partner. The game deals with logic and also reviews addition, subtraction, multiplication and division.

6. Division review $C$

Two digit division problems a re given for review. Half of the problems must be checked by multiplying.

7. Division review game

This is a game, played with a partner, to review all concepts of the division unit.

8. Division review $D$

Two digit division problems are reviewed, such as $4 3 \longdiv { 3 1 4 9 }$.

9. Krypto Cards

This game is played alone. It deals with logic and is also a review of addition, subtraction, multiplication and division.

10. Division review $\mathrm{E}$

Two digit division problems are reviewed, such as $3 6 \longdiv { 4 6 8 7 5 }$.

\section{Division Fun Game}

This game is played with a partner. The students play a board game and keep track of their dice rolls. They use this data to construct a giant division problem. 
12. Whale of a division problem

One giant problem is given to review division and to show the students they can handle all types of division. The long problem is written on a colored whale picture.

13. Division review test

This test reviews all types of division problems found in the three sections of the division unit. 


\author{
APPENDIX B \\ PLOTTING COORDINATES ON A GRID \\ TASK CARD DETAILS
}

\title{
Introduction of the Ordered Pairs Unit
}

1. Introduction of the ordered pairs unit

The students read an introduction to the unit and then copy the definitions of necessary terms.

2. City map game

This game is played with a partner. It helps the students learn to locate positions on a grid.

3. Introducing ordered pairs

The students are introduced to grid symbols by reading and answering questions from a cartooned instruction sheet. They also learn to locate points on a grid.

4. Introducing plotting points

Through a cartooned instruction sheet, the students review how to locate points on a grid and how to name the point location.

5. Plotting points $A$

Instructions are given for plotting points which create the word "WOW":

6. Plotting points $B$

Instructions are given for plotting points which create the outline of a ship.

7. Plotting points $\mathrm{C}$

Instructions are given for plotting points which create the outline of a dog.

8. $X$ and $Y$ coordinates

Information is given for the students to copy, telling how to properly name the "x axis" and the "y axis".

9. Plotting points $\mathrm{D}$

Instructions are given for plotting points which create a complicated polyhedra figure. 
10. Plotting points $\mathrm{E}$

Instructions are given for plotting points which create a complicated polyhedra figure.

11. Plotting points $\mathrm{F}$

Instructions are given for plotting points which create a complicated plyhedra figure.

12. Clue Game for ordered pairs

This game is played with a partner. The regular game of Clue is played. However, each time a player wants to take a turn, he must draw a problem card about this unit and answer it correctly on his paper.

\section{Using $X$ and $Y$ Grids}

1. Riddle math

The students try to answer a riddle by decoding the letters on a grid.

2. Coded message

Ordered pairs are given which the students must find on a lettered grid. A message will be revealed.

3. Changing the size of coordinate squares

The same set of ordered pairs are plotted four times. Each time, the vertical and horizontal scales have been altered. The shape of a Christmas tree is created, but it is distorted in a different way each time it is plotted on the grids.

4. Battleship \#1

This game is played with a partner to reinforce the concept of finding location on a grid. Only the $X$ and $Y$ axis are used.

5. Proportional drawing \#1 (of Africa)

The students enlarge a map of Africa. The model map is on a $1 / 4^{\prime \prime}$ grid and must be enlarged to fit a $1 / 2$ " grid. A line on the small grid should be located on a corresponding position on the large grid.

6. Proportional drawing \#2 (of a robot)

The students enlarge a sketch of a robot. The model robot is on a $1 / 4^{\prime \prime}$ grid and must be enlarged to fit a $1 / 2^{\prime \prime}$ grid. A line on the small grid should be located on a corresponding position on the large grid. 
7. Make your own proportional drawings

The students find a picture in a magazine which they cover with a $1 / 4 "$ grid and enlarge to a $1 / 2 "$ grid.

8. Five-In-A-Row

This game is played with a partner to reinforce the idea of finding location on a grid.

9. Woodley and Carol

A Five-In-A-Row game is recorded as ordered pairs. The student plays the game by himself to see if Woodley or Carol won the game. Plotting ordered pairs is reinforced.

Positive and Negative Numbers on a Grid

1. Negative and positive number graphing

The students copy the definitions and diagrams presented on the task card. Plotting coordinates is now being expanded to include negative numbers.

2. Mr. Pig

Instructions are given for plotting points which create a pig. Both negative and positive numbers are used.

3. Kanga

Instructions are given for plotting points which create a kangaroo. Both negative and positive numbers are used.

4. The hare

Instructions are given for plotting points which create a large hare. Only positive numbers are used, for review.

5. Expanded Battles hip Game \#2

This game is played with a partner to reinforce the concept of finding location on a grid. Negative and positive numbers are used.

6. Drawing your own ordered pair picture

The students create their own ordered picture. They then make a list of the ordered pairs and give the list to the teacher. The teacher must be able to successfully make the picture from the ordered pair list, without ever having seen the original picture. 


\section{APPENDIX C}

\section{GRAPHING UNIT TASK CARD DETAILS}

\section{Line Graph Unit}

1. Graphing definitions card

Definitions are given for the student to copy.

2. "Hamburgex" line graph

A simple line graph is given and the student answers questions from the data.

3. "Snowflake" line graph

The student makes a simple line graph from data that is given. Questions are answered about the data.

4. "Pigs" line graph

The student makes a more detailed line graph from data that is given. Questions are answered about the data.

5. Planning your own line graph

Information is given, which the student copies, about how to plan the vertical scale of a graph.

6. "Feather Park" line graph

The student makes a line graph from data that is given. The student must also figure the vertical scale for the first time, Questions are answered about the data.

7. Your own Heffalump line graph

The student makes a line graph from data that is given. The vertical scale must also be made and questions must be answered about the data.

8. Comparing data using one line graph

The student copies information about comparing two sets of data. Two sets of data are to be studied and questions answered.

9. "Money" line graph

The student makes a more complicated line graph from the data that is given. Two line graphs are drawn on the same grid to show comparisons. Questions are answered about the data. 
10. "Precipitation" line graph

The student studies two side-by-side line graphs and answers questions about the data.

11. "Broken windows" line graph

The student copies information about the sequence of the vertical scale on side-by-side line graphs. Questions are answered on the two side-by-side line graphs the student drew from the data given.

12. Giant chart line graphs

Six large line graphs are constructed by the student showing normal monthly precipitation in selected U.S. cities.

13. Make your own line graph

The student designs pretend data and makes his own line graph.

\section{Bar Graph Unit}

1. Bar graph background

Information is given on bar graphs, which the student copies.

2. Ballpark diamonds bar graph

The student studies a bar graph and answers questions about the data.

3. Pirate ship bar graph

The student makes a simple bar graph from data that is given. Questions are answered about the data.

4. Weather graph game

This game is played with a partner. The game reinforces bar graphing skills.

5. Your choice bar graph

The student designs pretend data and makes his own bar graph.

\section{Double Bar Graph Unit}

1. Double bar graph background

Information is given on double bar graphs, which the student copies. 
2. Farm fun double bar graph

The student studies an example of a double bar graph and answers questions about the data.

3. Favorite subjects double bar graph

The student makes a double bar graph from the data that is given. Questions are answered about the data.

4. Doctors and dentists double bar graph

The student makes a double bar graph from the data that is given.

5. Your choice double bar graph

The student designs pretend data and makes his own double bar graph.

6. Review of graphing

The Aggravation Game is played with a partner. The regular game is played. However, each time a player wants to take a turn, he must draw a problem card about this unit and answer it correctly on his paper. 


\section{APPENDIX D}

\section{GEOMETRY UNIT TASK CARD DETAILS}

\section{Lines, Points and Planes Unit}

1. Geometry definitions card Background information on the geometry unit is given for the student to copy.

2. Introduction to geometry terms: Points Information on points is given for the student to read. Questions are answered over the reading.

3. Introduction to geometry terms: Curves Information on curves is given for the student to read. Questions are answered over the reading.

4. Introduction to geometry terms: Lines, Line Segments, Rays Information on lines, line segments, and rays is given for the student to read. Questions are answered over the reading.

5. Introduction to geometry terms: Planes Information on planes is given for the student to read. Questions are answered over the reading.

6. Love letters

The student finds a hidden "love letter" word by finding all true statements on geometry terms in a list of statements.

7. Name game

The student finds a five word message by answering a series of questions on geometry terms.

8. Parallel, perpendicular and skew lines

The student copies definitions and examples of parallel, perpendicular and skew lines.

9. What did one tail pipe say to the other?

A riddle is answered by finding correct examples of parallel, perpendicular and skew lines on a diagram. 
10. Geometry terms review

The student copies review information on geometry terms.

11. Using geometry terms

The student studies a figure made up of various geometry terms (as represented in a figure) and answers questions.

12. Finding geometry terms in the world

The student is given a list of geometry terms and must find a certain number of them represented in the natural world.

13. Which one differs?

The student must study designs carefully to pick out which design in each series is different from the other designs.

14. Line Design \#1

The student is given numbered vertical and horizontal lines.

Numbers are connected to form curves, but by drawing straight lines.

15. Line Design \#2

The student is given numbered vertical and horizontal lines.

Numbers are connected to form curves, but by drawing straight lines.

16. Euler lines \#1 and \#2

The student tries to trace various figures without retracing his lines. He then follows Euler's rules to determine which figures truly are traceable.

$\underline{\text { Polygon Unit }}$

1. Profile Puzzle \#1

The student looks at a profile of a wooden block sculpture and then tries to find its view from the top from sixteen choices.

2. Profile Puzzle \#2

The student must match twelve top views of wooden block scuptures with the correct side views.

3. Star search

The student studies lines which overlap. These lines crisscross a group of stars. The student has to figure how many stars are in each set of lines. 
4. Perimeter and area

The student copies the card telling about perimeter and area.

5. Perimeter code

The student finds the perimeter of fourteen figures. Each figure is represented by a letter. A message will be decoded when the perimeters are figured correctly.

6. A square deal

The student figures the area of large letters which have been placed on a grid. A message will be decoded when the areas have been figured correctly.

7. Constellation area code

The student figures the area in square units of star constellations.

8. The meaning of congruent

The student copies the sentences and examples of congruent shapes.

9. Practice with congruent shapes

The student draws three boxes containing congruent shapes and three boxes which are shapes that are not congruent.

10. Which are not congruent?

The student studies thirty shapes and decides which shapes are not congruent.

11. Plygon definition card

The student makes a chart of triangles, quadrilaterals, pentagons, hexagons, heptagons, octagons and decagons. The chart shows a sketch of each shape, tells how it is names, tells the number of sides, names the sides, tells the number of vertices and names the vertices.

12. S. S. Polygon card

The student identifies various plygons on the picture of a ship. Each plygons is represented by a number. When the polygons are properly identified, a message will appear.

13. Georule activities

The student uses a georule to form shapes listed on the card.

The student draws the shape on his paper. 


\section{Circles Unit}

1. Circle definitions

The student copies definitions and a diagram which relate to circles.

2. Practicing with circle definitions

The student studies a labeled circle and answers questions about the parts of the circle.

3. Chords and tangents

The student copies definitions of chords and tangents and then answers questions about them, from a given diagram.

4. Degrees of a circle

The student copies circle and semi-circle definitions. The student then answers questions about circle degrees.

5. Which two differ?

A poster is studied and the student must pick out which two circles on the poster differ.

6. Using a compass to make circles Information is given on how to use a compass to make circles. The student constructs circles from a given list.

7. More compass problems

The student constructs additional circles from a given list.

8. Remembering the parts of a circle

The student constructs a circle and its parts from a given list.

9. Figuring pi

The student copies the information about pi. He then figures pi with a tin can.

10. Find a match

The student copies the formula for circumference. He works twenty circumference problems and ends with a clever saying, since each problem corresponds to a letter. Letters and numbers are matched at the end of the exercise.

11. Line-up

The student copies the formula for area. The student works the problems and puts the matching letters in boxes to form a me ssage. 
12. Hidden message

The student works circle problems. He matches corresponding numbers and letters to arrive at a hidden message.

13. What do butches call their big dance?

The student answers word questions about circles. He matches corresponding letters with answers to answer a riddle at the end of the exercise.

14. Concentric circles

The students have shown seven circles and they must decide which are concentric and which are not.

15. Compare poster

A poster is studied to find a comparison of circles. Two sets of circles are in an A:B relationship. The student must then find the pattern and figure $C$ :?

16. Round geoboard

The student constructs various polygons from a list on a round geoboard.

17. Line Design $A$ and $B$

The student constructs circular line designs

18. Circles in the real world

The student finds examples of circles in the real world, either in a man-made environment or the natural world.

19, Weave paths to the center

The student studies a poster and tries to weave his way to the center of a complicated maze of circular pathes.

20. Perfect ellipse

The student draws at least one ellipse, using string, pins and a pencil.

21. Ovals

The student does two oval experiments, using a flashlight and a drinking glass. The student then draws an ellipse.

22. Parabola

The student draws one example of a parabola in nature or the man-made world. 
23. Spirals

The student makes at least one spiral, using a board, string and nails.

24. Helix

The student makes a helix for his pencil and writes the procedure on his paper.

\section{Angles Unit}

1. Angles definitions

The student copies angle definitions on his paper and answers questions on angles.

2. Measuring angles

The student copies information on measuring angles with a protractor. He practices measuring angles.

3. Measuring angles for practice

The student measures ten angles and explains the measurement in relation to 180 degrees.

4. Daffynition decoder

The student measures angles, each of which correspond to a letter. Daffy definitions appear when the angles have been correctly measured.

5. What do you call two spiders who just got married?

By correctly measuring angles a riddle is answered.

6. Congruent angles

The student copies information on congruent angles and then he answers questions on congruency.

7. Where do electric eels do business?

The student works with congruent angle problems, and answers a riddle at the end of the exercise.

8. Perpendicular angles Information on perpendicular angles is given for the student to copy and then questions are to be answered.

9. Constructing right angles with a compass.

The student reads the directions for constructing a right angle 
with a compass and then makes his own.

10. More angle words

The student copies the card which gives the student a greater background on angle terminology.

11. Angles with a georule

The student creates various angles, from a list, with a georule. A picture of each angle is required.

12. Angles on a map

Using a map of Hillsboro, the student locates seventeen different types of angles.

13. Construct your own angles

A list of angles is given to the student to construct with a compass.

14. What did Orgo say when someone stole his soap and towel?

The size of angles are determined and placed in a graduating order. If done properly, a riddle is answered.

Triangle Unit

1. Triangle definitions card

The student copies information on triangles and answers questions.

2. Triangle puzzle pieces

The student puts together triangle puzzles, following a list of the required number and complexity of the puzzles.

3. Triangle theorem

The student arranges triangles in a specified order to decode

a message.

4. Triangle area and perimeter

The student copies the information on triangle area and perimeter.

5. Hidden triangle

The student figures the area and perimete $r$ of various triangles in order to discover a hidden message. 
6. Order sorter

The order of the triangles from smallest to largest is written. If the directions are followed, a word is decoded.

7. Chinese puzzle

The area is figured for eleven triangles and a saying of Confucious remains.

8. Maze daze

The student figures the area and perimeter of triangles; he will follow a maze successfully if the problems are correct.

9. Triangle square units card

The student learns to figure the area of a triangle by using square units. Careful reading is necessary and then problems are worked.

10. Count the triangles

Five figures are given, made out of many triangles. The student must count the number of triangles within three of the figures.

11. Mea suring angles in triangles.

The student copies the information on measuring angles within triangles and answers the questions.

12. Who's who?

The student measures angles in a triangle. When the degrees are computed correctly, two humorous definitions will appear.

13. Construct an equilate ral triangle

The student reads and carries out the directions for constructing an equilateral triangle.

14. Triangle puzzle

This is a game of logic played alone. The game board is in the shape of a triangle. Pegs are jumped, trying to leave just one peg.

15. Congruence and similarity

Information is copied about congruence and similarity and questions are answered.

16. Using similar triangles for measurement

The student reads the directions and then measures a tree using this method. 
17. Creative posters with triangles

The student looks at the posters made up of many triangles, and recreates the poster on his own paper.

18. Pythagoream theorem

The student copies the information on the pythagoream theorem and answers quesstions using the theorem.

\section{Quadrilaterals Unit}

1. Quadrilateral definitions

The student copies a chart of seven types of quadrilaterals and answers questions.

2. Square geoboard activities

From a list, the student creates various quadrilaterals on a square geoboard

3. Triangles and quadrilaterals

Word questions are answered about triangles and quadrilaterals. When the directions are followed correctly, a message is discovered.

4. Square puzzles

The student puts together square puzzles, following a list of the required number and complexity of the puzzles.

5. What is the title of this picture?

The area of rectangles is figured and a special title is decoded.

6. Why did Orgo use yeast and shoe polish?

The area of rectangles is figured and a riddle is answered.

7. House plans

After studying a house plan, the student answers questions about the area of the house. The student designs his ideal dream-house and figures the area, perimeter and cost per square foot, based on information given.

8. Geometry: Plane and Fancy

The area of plygons is figured and a message is decoded. 
9. A whole thing

Fractional parts of polygons are figured, off of an airplane diagram. The fractional parts are determined by figuring areas.

10. Square it!

A puzzle is given in which ten congruent squares are to be made out of two squares which meet on the diagonal.

11. Hi-Jinx puzzle

The student puts together this Hi-Jinx puzzle, following a list of the required number and complexity of the problems.

12. Count the squares

A.figure, made of many overlapping squares, is given. The student must count the number of squares correctly, within four.

13. Pentominoe puzzle

The student tries to arrange the twelve pentominoe puzzle pieces on a $6 \times 10 \mathrm{grid}$.

14. Universe pentominoe game

The student plays the game of logic with a partner. As the game progresses, the student becomes more and more familiar with the twelve standard pentominoe puzzle pieces.

15. Quadrilateral quest

The student is given a set of five quadrilaterals. He determines the midpoint of each and connects them, always forming a parallelogram.

16. Cutting and fitting

The student is given six shapes. With each shape he is to cut it in two parts which will form a square.

17. Square reverse puzzle

This logic game is played alone. On a square playing board, pegs are jumped, trying to reverse the top and bottom sets.

18. Make your own tangram

The student follows the steps to make his own tangram.

19. Tangram history card

The student copies the history of the tangram. 
20. Tangram picture card

The student creates five pictures, using all seven pieces of his tangram for each picture.

21. Tangram chart

The student completes a chart, stating "possible" or

"impossible" to various tangram puzzles.

22. Tangram puzzle card

Shapes are given and the student must fit his tangram pieces on shapes so they fit exactly.

23. Switch 'em game

This logic puzzle is played alone. Pegs are jumped along a row of nine boxes. The object is to switch the top markers to the bottom and the bottom markers to the top.

24. Tit-Tat-Toe and variations

With a partner, the student plays six variations to tit-tat-toe.

25. Patterned polygons

The student arranges four hexagons, squares, circles and triangles so that every row of a $4 \times 4$ grid has a different shape and color figure. Every shape is represented by all four colors.

26. Design matrix puzzle

Six sections of a puzzle are arrange: so the same design doesn't appear twice in the same column, row or diagonal.

27. Locate three exceptions

On this poster, students look at 54 squares and decide which three are not congruent.

\section{Larger Polygons Unit}

1. Larger polygon definitions review

The student copies information which reviews larger polygons definitions.

2. Changing figures

The student uses a square geoboard to make the figures shown on his list. 
3. Adding corners

Using a square geoboard, the student begins with a 3-cornered figure and continues to change one corner at a time, creating a variety of polygons.

4. Subtracting corners

Using a square geoboard, the student begins with a 6-cornered figure and continues to change one corner at a time to get back down to a 3 -cornered figure.

5. What's the pentagon?

The student researches to find out what famous building in the U.S. is called the pentagon.

6. Find five hidden stars

Using a poster, the student tries to find five hidden stars.

7. Hexagon puzzle pieces

The student puts together hexagon puzzles, following a list of the required number and complexity of the puzzles.

8. A square hexagon and pentagon?

The student changes a puzzle of one shape (either a hexagon or pentagon) to form the shape of a square.

9. Magic Hexagon

Using a "honey comb" of hexagons, the students fill in the missing numbers like a giant magic square.

10. Hex game

With a partner, the student plays the hex game of logic:

11. Snowflake geometry

The student studies the snowflakes on the card and finds the two that are identical.

12. Snowflake game

The student plays this game alone or with a partner, trying to put the snowflake puzzle together.

13. Hidden shapes

The student studies some designs and discovers which is the optical illusion. 
14. Hexoctomania game

This game is played with a partner. The student tries to cover "check shapes" with triangle pieces, trying to make the largest plygons possible.

15. Puzzle patterns

The student puts the puzzle patterns together following a list of the required number and complexity of the puzzles.

16. Code line \#1 and \#2

The student answers questions over polygons, matching answers with numbers, and arriving with messages at the end of the cards.

17. Tying paper knots

Following the directions, the student ties paper knots to form a square, pentagon, hexagon and heptagon.

18. Plygon card game

The student plays the polygon card game with a partner. The game is a review over polygon concepts.

19. Walk-through paper

The student makes a strip of walk-through paper by following the directions on the card.

20. Mobius strip

The student makes four types of mobius strips, as indicated by the directions to the student.

21. Make a trihexaflexagon

The student makes a trihexaflexagon.

22. Make a hexahexaflexagon

The student makes a hexahexaflexagon

Plyhedra Unit

1. Plyhedra definitions

The student copies the polyhedra definitions information.

2. Cutting and folding geometric forms

The student copies or summarizes the Gree philosophy toward the perfect polyhedra. The student then makes a tetrahedron, 
a cube, an octahedron, a dodecahedron, and a icosahedron.

3. Polyhedra chart

The student makes a chart analyzing the five regular polyhedra according to number of vertices, number of edges, number of faces, and face shapes.

4. Twister cube

The student puts together a twister cube.

5. Instant insanity

The student arranges the four cubes in the proper order so that all six sides have a different pattern of colors showing.

6. Soma cube

The student puts the soma cube together

7. Cube faces

The student studies pictures of cubes in various positions. He tries to figure out what part of each cube is hidden.

8. Neurotic nines

The student tries to arrange the nine cubes so the numbers on each cube add up to nine in every direction, including on the bottom and sides of the cubes.

9. Octahedron faces card

The student studies pictures of octahedrons in various positions. He tries to figure out what part of each octahedron is hidden.

10. Cubes and patterns

The student studies pictures of cubes in various positions. $\mathrm{He}$ tries to figure out what pattern is hidden opposite each of a list of patterns. Each face of a cube has a pattern on it.

11. Cube flip and turn

The student studies pictures of cubes in various positions. He tries to figure out what part of each cube is hidden.

12. What is the difference between a donkey and a stamp? The student copies the formula for volume and then works the volume problems. The answer will also give the answer to a riddle. 
13. Cube code

The student computes the volume of various cubes. A message is formed by the answer.

14. The spider and the fly

The student figures the geodesic (shortest path between two points on a surface which is not flat) between a spider and a fly.

15. D-Stix constructions

The student makes at least four constructions with the $D$-Stix, following a given list.

16. Super structures

The student makes a variety of constructions with the super structures, following a given list.

17. Equilateral triangle icosahedron

This is an extra credit project, using equilateral triangle shapes to fit together to form a icosahedron sphere.

18. An icosahedron from circle shapes

This is an extra credit project, using circle shapes to fit together to form a icosahedron sphere.

\section{Geometry Enrichment}

Many additional geometry activities can be developed. These activities can include projects, further study, additional puzzles, nature study and much more. The student, upon reaching this point, checks with the teacher to set up projects he would like to pursue. A large box of possible topics is available in class, or the student can work on a project of his own. 